\title{
Control of Bond-Strain-Induced Electronic Phase Transitions in Iron Perovskites
}

Ikuya Yamada, ${ }^{*, a, b, c}$ Hidenobu Etani, ${ }^{b}$ Kazuki Tsuchida, ${ }^{\mathrm{b}}$ Shohei Marukawa, ${ }^{\mathrm{d}}$ Naoaki Hayashi, ${ }^{\mathrm{e}}$ Takateru Kawakami, ${ }^{\mathrm{f}}$ Masaichiro Mizumaki, ${ }^{\mathrm{g}, \mathrm{h}}$ Kenya Ohgushi, ${ }^{\mathrm{i}}$ Yoshihiro Kusano, ${ }_{\mathrm{j}}^{\mathrm{j}}$ Jungeun Kim, ${ }^{\mathrm{g}}$ Naruki Tsuji, ${ }^{\mathrm{g}}$ Ryoji Takahashi, ${ }^{\mathrm{b}}$ Norimasa Nishiyama, ${ }^{\mathrm{c}, \mathrm{k}, \dagger}$ Toru Inoue, ${ }^{\mathrm{k}}$ Tetsuo Irifune, ${ }^{\mathrm{k}}$ and Mikio Takano ${ }^{\mathrm{e}}$

${ }^{a}$ Nanoscience and Nanotechnology Research Center, Osaka Prefecture University, 1-2 Gakuen-cho, Naka-ku, Sakai, Osaka 599-8570, Japan

${ }^{b}$ Department of Chemistry, Graduate School of Science and Engineering, Ehime University, 2-5 Bunkyo-cho, Matsuyama, Ehime 790-8577, Japan

${ }^{c}$ Precursory Research for Embryonic Science and Technology (PRESTO), Japan Science and Technology Agency (JST), Chiyoda-ku, Tokyo 102-0075, Japan

${ }^{d}$ Department of Chemistry, Graduate School of Science, Osaka Prefecture University, 1-1 Gakuen-cho, Naka-ku, Sakai, Osaka 599-8531, Japan

${ }^{e}$ Institute for Integrated Cell-Material Sciences (iCeMS), Kyoto University, Yoshidaushinomiya-cho, Sakyo-ku, Kyoto 606-8501, Japan

${ }^{f}$ Department of Physics, College of Humanities and Sciences, Nihon University, Sakurajosui, Setagaya-ku, Tokyo 156-8550, Japan

${ }^{g}$ Japan Synchrotron Radiation Research Institute (JASRI), Sayo-cho, Sayo-gun, Hyogo 679-5198, Japan

${ }^{h}$ Core Research for Evolutional Science and Technology (CREST), JST, 5 Sanbancho, Chiyoda-ku, Tokyo 102-0075, Japan

${ }^{i}$ Institute for Solid State Physics (ISSP), University of Tokyo, 5-1-5 Kashiwanoha, Kashiwa, Chiba 227-8581, Japan ${ }^{j}$ Department of Applied Arts and Design, Kurashiki University of Science and the Arts, 2640 Nishinoura, Tsurajima-cho, Kurashiki, Okayama 712-8505, Japan

${ }^{k}$ Geodynamics Research Center (GRC), Ehime University, 2-5 Bunkyo-cho, Matsuyama, Ehime 790-8577, Japan 


\section{ABSTRACT}

Unusual electronic phase transitions in the $A$-site ordered perovskites $L n \mathrm{Cu}_{3} \mathrm{Fe}_{4} \mathrm{O}_{12}(L n$ : trivalent lanthanide

ion) are investigated. All $L n \mathrm{Cu}_{3} \mathrm{Fe}_{4} \mathrm{O}_{12}$ compounds are in identical valence states of $\operatorname{Ln}^{3+} \mathrm{Cu}_{3}^{2+} \mathrm{Fe}^{3.75+}{ }_{4} \mathrm{O}_{12}$ at high

temperature. $L n \mathrm{Cu}_{3} \mathrm{Fe}_{4} \mathrm{O}_{12}$ with larger $L n$ ions ( $L n=\mathrm{La}, \mathrm{Pr}, \mathrm{Nd}, \mathrm{Sm}, \mathrm{Eu}, \mathrm{Gd}, \mathrm{Tb}$ ) show an intersite charge transfer

transition $\left(3 \mathrm{Cu}^{2+}+4 \mathrm{Fe}^{3.75+} \rightarrow 3 \mathrm{Cu}^{3+}+4 \mathrm{Fe}^{3+}\right)$ in which the transition temperature decreases from 360 to $240 \mathrm{~K}$ with

decreasing $L n$ ion size. In contrast, $L n \mathrm{Cu}_{3} \mathrm{Fe}_{4} \mathrm{O}_{12}$ with smaller $L n$ ions ( $L n=\mathrm{Dy}$, Ho, Er, Tm Yb, Lu) transform into a

charge-disproportionated $\left(8 \mathrm{Fe}^{3.75+} \rightarrow 5 \mathrm{Fe}^{3+}+3 \mathrm{Fe}^{5+}\right)$ and charge-ordered phase below $\sim 250-260 \mathrm{~K}$. The former series

exhibits metal-to-insulator, antiferromagnetic, and isostructural volume expansion transitions simultaneously with intersite

charge transfer. The latter shows metal-to-semiconductor, ferrimagnetic, and structural phase transitions simultaneously

with charge disproportionation. Bond valence calculation reveals that the metal-oxygen bond strains in these compounds

are classified into two types: Overbonding or compression stress (underbonding or tensile stress) in the $\operatorname{Ln}-\mathrm{O}$ (Fe-O) bond

is dominant in the former series, while the opposite stresses or bond strains are found in the latter. Intersite charge transfer

transition temperatures are strongly dependent upon the global instability indices that represent the structural instability

calculated from the bond valence sum, whereas the charge disproportionation occurs at almost identical temperatures,

regardless of the magnitude of structural instability. These findings provide a new aspect of the structure-property

relationship in transition metal oxides and enable precise control of electronic states by bond strains. 


\section{INTRODUCTION}

Transition metal oxides have been extensively investigated because of a rich variety of interesting properties. ${ }^{1}$

Together with nominal valence tuning using chemical substitutions and cation/anion vacancies, the adjustment of local structure such as metal-oxygen bond lengths and bond angles is a key element to achieve fascinating properties. Several kinds of indices are proposed for characterizing crystal structures of compounds. Brown's bond valence model ${ }^{2,3}$ is widely used for estimating not only nominal valences but also the structural stability of certain compounds. The bond valence sum (BVS) is calculated from cation-anion bond lengths, and in normal cases, it matches the formal ionic valence. A difference between BVS and the ionic valence is called a bond discrepancy, which represents a steric bond strain, and their root mean square in the formula unit, global instability index (GII), ${ }^{3}$ can be used to empirically evaluate structural instability. ${ }^{4-6}$

Iron-based perovskites $A^{2+} \mathrm{Fe}^{4+} \mathrm{O}_{3}(A: \mathrm{Ca}, \mathrm{Sr}, \mathrm{Ba})$, which include unusual high valence $\mathrm{Fe}^{4+}$ ions, are known to demonstrate versatile electronic properties with structural modifications. The simple cubic perovskite $\mathrm{SrFeO}_{3} \mathrm{has}$ metallic conductivity down to low temperatures and displays complicated spin structures ${ }^{7-9}$ which are different from the isoelectronic $\mathrm{Mn}^{3+}$-based perovskites with $3 \mathrm{~d}^{4}$ electron configuration because of the difference in the charge transfer energy (energy for ligand-to-metal electron transfer), $\Delta_{\mathrm{CT}}$. The $\Delta_{\mathrm{CT}}$ is positive for $\mathrm{Mn}^{3+}(+1.8 \mathrm{eV})$ and negative for $\mathrm{Fe}^{4+}(-3$ eV). ${ }^{10,11}$ This discriminative electronic state also induces intriguing phenomena in other $A^{2+} \mathrm{Fe}^{4+} \mathrm{O}_{3}$ perovskites, such as the charge disproportionation (CD) of $2 \mathrm{Fe}^{4+} \rightarrow \mathrm{Fe}^{5+}+\mathrm{Fe}^{3+}\left(2 \mathrm{Fe}^{3+} \underline{L} \rightarrow \mathrm{Fe}^{3+} \underline{L^{2}}+\mathrm{Fe}^{3+}, \underline{L}\right.$ : ligand hole) in the orthorhombic perovskite $\mathrm{CaFeO}_{3}$ and the ferromagnetic alignment of $\mathrm{Fe}$ spins in the simple cubic perovskite $\mathrm{BaFeO}_{3} \cdot{ }^{12-15}$

The $A$-site ordered perovskites $A A^{\prime}{ }_{3} B_{4} \mathrm{O}_{12}$, in which the original $A$-sites are divided into an icosahedral 
coordinated $A$-site and a pseudo-square coordinated $A^{\prime}$ 'site (see Figure 1), have been extensively studied in recent years because of their fascinating structural and electronic features such as large magnetoresistance, giant dielectricity, heavy-fermion-like behavior, charge/orbital/spin-orderings, pressure-induced charge-disproportionation/ordering, and unusual high coordination. ${ }^{16-22}$ In particular, $\mathrm{Fe}^{4+}$-incorporated $A \mathrm{Cu}_{3} \mathrm{Fe}_{4} \mathrm{O}_{12}$ perovskites demonstrate highly intriguing phenomena due to their unusual electronic phase transitions. For instance, $\mathrm{Ca}^{2+} \mathrm{Cu}^{2+}{ }_{3} \mathrm{Fe}^{4+}{ }_{4} \mathrm{O}_{12}$ shows a charge disproportionation with a rock salt-type $\mathrm{Fe}^{3+} / \mathrm{Fe}^{5+}$ charge ordering, a ferrimagnetic ordering of $\mathrm{Cu}^{2+} \downarrow \mathrm{Fe}^{5+} \uparrow \mathrm{Fe}^{3+} \uparrow$, and a metal-semiconductor transition simultaneously at $210 \mathrm{~K}^{23}$ Instead, $\mathrm{Sr}^{2+} \mathrm{Cu}^{2+}{ }_{3} \mathrm{Fe}^{4+}{ }_{4} \mathrm{O}_{12}$, which contains a larger divalent cation at the $A$-site, displays a crossover-like intersite charge transfer featuring a negative thermal expansion between 170 and $270 \mathrm{~K}$, followed by a charge disproportionation with a relative abundance of $\mathrm{Fe}^{5+}: \mathrm{Fe}^{3+}$ of $\sim 1: 4 .^{24}$ Such considerable dependence of structural and electronic properties upon $A$-site ion size was also reported for the $A^{3+} \mathrm{Cu}^{2+}{ }_{3} \mathrm{Fe}^{3.75+}{ }_{4} \mathrm{O}_{12}$ perovskites. Figure 1 shows various crystal structures and electronic states for $A^{3+} \mathrm{Cu}_{3} \mathrm{Fe}_{4} \mathrm{O}_{12}(A=\mathrm{La}, \mathrm{Bi}, \mathrm{Y}){ }^{25-27} \mathrm{All}$ have an identical valence state of $A^{3+} \mathrm{Cu}^{2+}{ }_{3} \mathrm{Fe}^{3.75+}{ }_{4} \mathrm{O}_{12}$ at high temperature, crystallizing into the cubic $A A^{\prime}{ }_{3} B_{4} \mathrm{O}_{12}$-type perovskite with the space group $\operatorname{Im} \overline{3}$ (No. 204) and with paramagnetic and metallic properties. Upon cooling to low temperature, the valence state transforms into two distinct states. $\mathrm{LaCu}_{3} \mathrm{Fe}_{4} \mathrm{O}_{12}$ and $\mathrm{BiCu}_{3} \mathrm{Fe}_{4} \mathrm{O}_{12}$ show an intersite charge transfer (CT) transition of $3 \mathrm{Cu}^{2+}+4 \mathrm{Fe}^{3.75+} \rightarrow 3 \mathrm{Cu}^{3+}+4 \mathrm{Fe}^{3+}$ below $393 \mathrm{~K}(\mathrm{La})$ and $428 \mathrm{~K}(\mathrm{Bi})$, respectively. ${ }^{26,27}$ In contrast, $\mathrm{YCu}_{3} \mathrm{Fe}_{4} \mathrm{O}_{12}$ shows a CD transition of $8 \mathrm{Fe}^{3.75+} \rightarrow 5 \mathrm{Fe}^{3+}+3 \mathrm{Fe}^{5+}$ below $250 \mathrm{~K},{ }^{25}$ which is similar to that of $\mathrm{CaCu}_{3} \mathrm{Fe}_{4} \mathrm{O}_{12}$ rather than the $\mathrm{CT}$ transition of isoelectronic compounds. The resulting low-temperature phases in the $A^{3+} \mathrm{Cu}_{3} \mathrm{Fe}_{4} \mathrm{O}_{12}$ perovskites have different crystal structures and physical properties. The $A^{3+} \mathrm{Cu}_{3}^{3+} \mathrm{Fe}^{3+}{ }_{4} \mathrm{O}_{12}(A=\mathrm{La}, \mathrm{Bi})$ phase retains the $\operatorname{Im} \overline{3}$ space group, but the $\mathrm{Y}^{3+} \mathrm{Cu}^{2+}{ }_{3}\left(\mathrm{Fe}^{3+}, \mathrm{Fe}^{5+}\right)_{4} \mathrm{O}_{12}$ phase has two crystallographic $\mathrm{Fe}$ sites for $\mathrm{Fe}^{3+}$ and $\left(\mathrm{Fe}^{5+}{ }_{3 / 4} \mathrm{Fe}^{3+}{ }_{1 / 4}\right)$ ions because of charge 
ordering, lowering its symmetry to the space group $P n \overline{3}$ (No. 201) (Figure 1). Although the former electronic phase displays an insulator-like electrical conductivity with a large temperature dependence and an antiferromagnetic ordering of $\mathrm{Fe}^{3+}$ spins, the latter shows a metal-to-semiconductor-like transition with slight temperature dependence and a ferrimagnetic ordering of $\mathrm{Cu}^{2+}$ and $\left(\mathrm{Fe}^{3+}, \mathrm{Fe}^{5+}\right)$ spins. It is notable that such a considerable dependence of the electronic phases upon $A$-site ion size has never been reported in isoelectronic $A A^{\prime}{ }_{3} B_{4} \mathrm{O}_{12}$-type perovskites. ${ }^{28,29}$ To unveil the origin of the difference between CT and CD transitions for $A^{3+} \mathrm{Cu}_{3} \mathrm{Fe}_{4} \mathrm{O}_{12}$, we have performed structural analysis based on the bond valence models of $\mathrm{LaCu}_{3} \mathrm{Fe}_{4} \mathrm{O}_{12}$ and $\mathrm{YCu}_{3} \mathrm{Fe}_{4} \mathrm{O}_{12}$. In a previous paper, ${ }^{25}$ we proposed that intolerable strains (compression or tensile stress) on $A-\mathrm{O}$ and $\mathrm{Fe}-\mathrm{O}$ bonds, which are represented as an overbonding (underbonding) of $A-\mathrm{O}(\mathrm{Fe}-\mathrm{O}$ ) bonds, ${ }^{2,30}$ may become a driving force for CT, while the opposite type of bond strains do not induce a CT transition. However, the limited number of sample compounds could not allow us to conduct an in-depth study of the relationship between bond strains and electronic phases. In this paper, we show a systematic study of crystal structures, electronic states, and physical properties of $L n \mathrm{Cu}_{3} \mathrm{Fe}_{4} \mathrm{O}_{12}(L n$ : lanthanide, $\mathrm{La}, \mathrm{Pr}, \mathrm{Nd}, \mathrm{Sm}, \mathrm{Eu}, \mathrm{Gd}, \mathrm{Tb}, \mathrm{Dy}, \mathrm{Ho}, \mathrm{Er}, \mathrm{Tm}, \mathrm{Yb}, \mathrm{Lu})$, in which the $A$-site ion size may be precisely adjusted by lanthanide contraction from $\mathrm{La}^{3+}$ (Shannon's eight-coordinate ionic radius, $\left.{ }^{31} r_{\mathrm{La}}=1.16 \AA\right)$ to $\mathrm{Lu}^{3+}\left(r_{\mathrm{Lu}}=0.977 \AA\right.$ ), obtaining the whole electronic phase diagram of these compounds. Careful analysis of bond strains leads to the conclusion that the electronic phase transition in $L n \mathrm{Cu}_{3} \mathrm{Fe}_{4} \mathrm{O}_{12}$ is controlled by subtle differences in the types of bond strains on $\mathrm{Ln}-\mathrm{O}$ and $\mathrm{Fe}-\mathrm{O}$ bonds.

\section{EXPERIMENTAL}

A precursor was prepared by the polymerized complex method ${ }^{32}$ as in the synthesis of $\mathrm{YCu}_{3} \mathrm{Fe}_{4} \mathrm{O}_{12}{ }^{25}$ 
Stoichiometric amounts of lanthanide oxides (99.9\%), $\mathrm{Cu}\left(\mathrm{NO}_{3}\right)_{2} \cdot 3 \mathrm{H}_{2} \mathrm{O}(99.9 \%)$, and $\mathrm{Fe}\left(\mathrm{NO}_{3}\right)_{3} \cdot 9 \mathrm{H}_{2} \mathrm{O}(99.9 \%)$ were dissolved in nitric acid, to which a five-fold excess of citric acid and a one-fold excess of 1,2-ethanediol were added while stirring. The resulting solution was heated, while being stirred, up to $573 \mathrm{~K}$ and kept there for $1 \mathrm{~h}$ to dryness. Subsequently, the dried powder was fired using a furnace at $673 \mathrm{~K}$ for $1 \mathrm{~h}$ and $948 \mathrm{~K}$ for $12 \mathrm{~h}$ in air with occasional grindings. The obtained precursor with a nominal chemical composition of $L n \mathrm{Cu}_{3} \mathrm{Fe}_{4} \mathrm{O}_{10.5}$ was mixed with an oxidizing agent $\mathrm{KClO}_{4}$ $(99.9 \%)$ in a molar ratio of 2:1. The sample mixture was sealed off during the treatment in a platinum capsule with an inner diameter of 2.3-2.8 $\mathrm{mm}$ and a height of $4.0 \mathrm{~mm}$. The capsule was placed into a $(\mathrm{Mg}, \mathrm{Co}) \mathrm{O}$ pressure medium, and compressed to $15 \mathrm{GPa}$ using an high-pressure apparatus. The sample was subsequently heated to $1273-1473 \mathrm{~K}$ in $20 \mathrm{~min}$, kept at this temperature for $30 \mathrm{~min}$, and quenched to room temperature. The pressure was slowly released after the heat treatment. The obtained polycrystalline sample was washed several times with water, ethanol, and acetone.

The synchrotron X-ray powder diffraction (SXRD) experiments were performed at the BL02B2 beamline of SPring-8, Japan using samples contained in Lindemann glass capillary tubes with an inner diameter of $0.2 \mathrm{~mm}$. The wavelength used was determined to be $0.42085 \AA$ using a $\mathrm{CeO}_{2}$ standard. Structure parameters were refined by Rietveld analysis using the program RIETAN-FP. ${ }^{33}$ The crystal structures were drawn using the VESTA software. ${ }^{34}$ An absorption correction was not considered in the refinement because the absorption effect was expected to be negligibly small. Electron diffraction (ED) patterns of $\mathrm{LuCu}_{3} \mathrm{Fe}_{4} \mathrm{O}_{12}$ were collected at 300 and $200 \mathrm{~K}$ using a transmission electron microscope (TOPCON, EM-002B).

The ${ }^{57} \mathrm{Fe}$ Mössbauer spectroscopy measurements were performed for selected samples of $L n \mathrm{Cu}_{3} \mathrm{Fe}_{4} \mathrm{O}_{12}(L n=\mathrm{Eu}$, $\mathrm{Tb}, \mathrm{Dy}, \mathrm{Lu})$ in transmission geometry using ${ }^{57} \mathrm{Co} / \mathrm{Rh}$ as a radiation source and $\alpha$-Fe as a control for velocity calibration 
and isomer shift. Collected Mössbauer spectra were fitted computationally using the Lorentzian function. Soft X-ray

absorption spectroscopy (XAS) and magnetic circular dichroism (MCD) for the $\mathrm{Cu} L_{2,3^{-}}$and $\mathrm{Fe} L_{2,3^{-}}$edges were measured

at $15 \mathrm{~K}$ in an external magnetic field of $19 \mathrm{kOe}$ using a total electron yield method at the BL25SU and BL27SU beamlines

of SPring-8. Magnetization measurements were conducted using a superconducting quantum interference device (SQUID,

Quantum Design MPMS-XL) between 5 and $400 \mathrm{~K}$ under external fields up to $50 \mathrm{kOe}$. Electrical resistivity was measured by the standard four-probe method using a Quantum Design Physical Properties Measurement System (PPMS).

\section{RESULTS AND DISCUSSION}

We successfully obtained high-quality samples of $L n \mathrm{Cu}_{3} \mathrm{Fe}_{4} \mathrm{O}_{12}(L n=\mathrm{Pr}, \mathrm{Nd}, \mathrm{Sm}, \mathrm{Eu}, \mathrm{Gd}, \mathrm{Tb}, \mathrm{Dy}, \mathrm{Ho}, \mathrm{Er}, \mathrm{Tm}$,

$\mathrm{Yb}, \mathrm{Lu}$ ), and using X-ray diffractometry we were able to split them into two classes. Figure 2a shows the SXRD patterns

for $L n \mathrm{Cu}_{3} \mathrm{Fe}_{4} \mathrm{O}_{12}$ at $300 \mathrm{~K}$. The primary phase for all of the compounds is the cubic $A A^{\prime}{ }_{3} B_{4} \mathrm{O}_{12}$-type perovskite (space

group $\operatorname{Im} \overline{3}$, No. 204) with a lattice constant $a=7.303-7.429 \AA$. All are single-phase or contain a very small amount of impurity phase(s) (presumably, up to a few wt\%). Figure 2b shows the SXRD patterns for $\operatorname{LnCu}_{3} \mathrm{Fe}_{4} \mathrm{O}_{12}$ near the 246 Bragg reflection. The 246 peak monotonically shifts to higher angle with decreasing $r_{L n}$, corresponding to a unit cell volume shrinkage from $\sim 410 \AA^{3}$ for $\mathrm{LaCu}_{3} \mathrm{Fe}_{4} \mathrm{O}_{12}$ to $\sim 390 \AA^{3}$ for $\mathrm{LuCu}_{3} \mathrm{Fe}_{4} \mathrm{O}_{12}$ at this temperature. Figure 2c shows the temperature dependence of the unit cell volume, $V$, for $L n \mathrm{Cu}_{3} \mathrm{Fe}_{4} \mathrm{O}_{12}$. An abrupt volume change is observed in $\mathrm{LaCu}_{3} \mathrm{Fe}_{4} \mathrm{O}_{12}$ at $360 \mathrm{~K}$, which is attributed to the CT transition, as previously reported. ${ }^{26}$ Similar anomalies observed in $L n \mathrm{Cu}_{3} \mathrm{Fe}_{4} \mathrm{O}_{12}$ with larger $\mathrm{Ln}$ ions $(\mathrm{Ln}=\mathrm{Pr}, \mathrm{Nd}, \mathrm{Sm}, \mathrm{Eu}, \mathrm{Gd}, \mathrm{Tb})$ at temperatures between 230 and $320 \mathrm{~K}$ may also be attributed to CT transitions (see also the XRD patterns collected in a temperature range of 100-450 K shown in Figure S1 
in the Supporting Information). Note that the CT transition temperatures tend to lower with decreasing $r_{L n}$. On the other hand, $L n \mathrm{Cu}_{3} \mathrm{Fe}_{4} \mathrm{O}_{12}$ with smaller $L n$ ions ( $\left.L n=\mathrm{Dy}, \mathrm{Ho}, \mathrm{Er}, \mathrm{Tm}, \mathrm{Yb}, \mathrm{Lu}\right)$ display no clear anomaly between 100 and $450 \mathrm{~K}$, implying an absence of CT transitions.

The valence states of the $L n \mathrm{Cu}_{3} \mathrm{Fe}_{4} \mathrm{O}_{12}$ were investigated using the bond valence method. ${ }^{2}$ Rietveld refinement was conducted based on the SXRD data at temperatures between 100 and $450 \mathrm{~K}$. Table 1 lists the structure parameters obtained from Rietveld refinement for the data at $300 \mathrm{~K}$ (also see the SXRD profiles and the fitting results in Figure S2 of the Supporting Information). A stoichiometric model was adopted for simplicity because structural disorders in these compounds were expected to be insignificant, though a few atom $\%$ of $\mathrm{Fe}$ ions incorporated into the $\mathrm{Cu}$ sites were confirmed by Mössbauer spectroscopy (shown later). The Rietveld refinement at this temperature gave excellent reliability factors and a goodness of fit (GOF), showing $R_{\mathrm{wp}}<8 \%, R_{\mathrm{B}}<2 \%$, and GOF $<1.1$. The BVS values of $L n, \mathrm{Cu}$, and $\mathrm{Fe}$ ions for $L n \mathrm{Cu}_{3} \mathrm{Fe}_{4} \mathrm{O}_{12}(L n=\mathrm{Nd}, \mathrm{Sm}, \mathrm{Eu}, \mathrm{Gd}, \mathrm{Tb}, \mathrm{Dy}, \mathrm{Ho}, \mathrm{Er}, \mathrm{Tm}, \mathrm{Yb}, \mathrm{Lu})$ are 2.61-3.44, 2.00-2.03, 3.64-3.80, respectively, which are close to $+3,+2$, and +3.75 at this temperature, respectively. This reflects that these compounds have $\mathrm{Ln}^{3+} \mathrm{Cu}_{3}^{2+} \mathrm{Fe}^{3.75+}{ }_{4} \mathrm{O}_{12}$ valence states (see Table 1), while the BVS values of $L n, \mathrm{Cu}$, and $\mathrm{Fe}$ ions for $\mathrm{LaCu}_{3} \mathrm{Fe}_{4} \mathrm{O}_{12}$ and $\mathrm{PrCu}_{3} \mathrm{Fe}_{4} \mathrm{O}_{12}$ are 3.32-3.46, 2.88-2.89, and 3.05-3.11, respectively, suggesting that their appropriate ionic models are $\mathrm{Ln}^{3+} \mathrm{Cu}_{3}^{3+} \mathrm{Fe}^{3+}{ }_{4} \mathrm{O}_{12}$. The SXRD patterns at $100 \mathrm{~K}$ were indexed in the cubic $A A^{\prime}{ }_{3} B_{4} \mathrm{O}_{12}$-type perovskite structure for all. Several compounds $(\mathrm{Ln}=\mathrm{Gd}, \mathrm{Tb}, \mathrm{Dy}, \mathrm{Ho})$ contained very small amounts $(1-3 \%)$ of isostructural secondary phases. These phases are presumably attributed to off-stoichiometry and/or crystallites strained by external stress, which may unexpectedly give rise to other types of phase transitions, and therefore we exclude secondary phases from the discussion. Table 2 lists the structure parameters obtained from Rietveld refinement for the data at $100 \mathrm{~K}$ (see also the SXRD profiles 
and the fitting results in Figure $\mathrm{S} 3$ in the Supporting Information). The SXRD data of $L n \mathrm{Cu}_{3} \mathrm{Fe}_{4} \mathrm{O}_{12}(L n=\mathrm{La}, \mathrm{Pr}, \mathrm{Nd}, \mathrm{Sm}$, $\mathrm{Eu}, \mathrm{Gd}, \mathrm{Tb})$ were refined based on the $\operatorname{Im} \overline{3}$ space group. The BVS values of $L n, \mathrm{Cu}$, and $\mathrm{Fe}$ ions for these compounds are 2.96-3.50, 2.90-2.92, and 3.07-3.19, respectively, all of which are close to +3, confirming that the $\operatorname{Ln}^{3+} \mathrm{Cu}^{3+}{ }_{3} \mathrm{Fe}^{3+}{ }_{4} \mathrm{O}_{12}$ valence states are appropriate. These results allow us to conclude that the volume expansions are associated with CT transitions of $3 \mathrm{Cu}^{2+}+4 \mathrm{Fe}^{3.75+} \rightarrow 3 \mathrm{Cu}^{3+}+4 \mathrm{Fe}^{3+}$. The $\mathrm{ED}$ data of $\mathrm{LuCu}_{3} \mathrm{Fe}_{4} \mathrm{O}_{12}$ displayed a symmetry lowering from $\operatorname{Im} \overline{3}$ at $300 \mathrm{~K}$ to $P n \overline{3}$ (No. 201) at $200 \mathrm{~K}$ (see Figure S4 in the Supporting Information). This implies a charge ordering of Fe ${ }^{3+}$ and $\left(\mathrm{Fe}^{5+}{ }_{3 / 4}, \mathrm{Fe}^{3+}{ }_{1 / 4}\right)$ ions in the charge-disproportionated phase, as reported previously in $\mathrm{YCu}_{3} \mathrm{Fe}_{4} \mathrm{O}_{12}{ }^{25}$ Hence, we made structure refinement using the SXRD data of $\mathrm{LuCu}_{3} \mathrm{Fe}_{4} \mathrm{O}_{12}$ at $100 \mathrm{~K}$ in the $P n \overline{3}$ space group, obtaining a reliable charge-ordered structure (Table 2 and Figure S3 in the Supporting Information). Also the SXRD data of $L n \mathrm{Cu}_{3} \mathrm{Fe}_{4} \mathrm{O}_{12}(\operatorname{Ln}$ $=\mathrm{Dy}, \mathrm{Ho}, \mathrm{Er}, \mathrm{Tm}, \mathrm{Yb})$ at $100 \mathrm{~K}$ could be reasonably refined in the $P n \overline{3}$ space group, showing two distinct Fe-O bond lengths for the charge-ordered structure. Therefore, we conclude that $\mathrm{CD}$ phase transitions $\left(8 \mathrm{Fe}^{3.75+} \rightarrow 5 \mathrm{Fe}^{3+}+3 \mathrm{Fe}^{5+}\right)$ occur at low temperatures between 100 and $300 \mathrm{~K}$ for the $L n \mathrm{Cu}_{3} \mathrm{Fe}_{4} \mathrm{O}_{12}$ with smaller $L n$ ions $(L n=\mathrm{Dy}, \mathrm{Ho}, \mathrm{Er}, \mathrm{Tm}, \mathrm{Yb}, \mathrm{Lu})$ instead of CT transitions.

The ${ }^{57} \mathrm{Fe}$ Mössbauer spectroscopy data confirmed the above-mentioned structure analysis results. Figure 3 shows Mössbauer spectra for selected $L n \mathrm{Cu}_{3} \mathrm{Fe}_{4} \mathrm{O}_{12}$ compounds $(\mathrm{Ln}=\mathrm{Eu}, \mathrm{Tb}, \mathrm{Dy}, \mathrm{Lu})$ at $4 \mathrm{~K}$ and at room temperature, and their hyperfine parameters are listed in Table 3 . For all of the compounds, a primary component is a singlet with an isomer shift $(I S)$ of $0.16-0.18 \mathrm{~mm} \mathrm{~s}^{-1}$ at room temperature. These $I S$ values are similar to that reported for $\mathrm{Y}^{3+} \mathrm{Cu}^{2+}{ }_{3} \mathrm{Fe}^{3.75+}{ }_{4} \mathrm{O}_{12}(I S$ $=0.16 \mathrm{~mm} \mathrm{~s}^{-1}$ at $\left.290 \mathrm{~K}\right)^{25}$ rather than $\mathrm{La}^{3+} \mathrm{Cu}^{3+}{ }_{3} \mathrm{Fe}^{3+}{ }_{4} \mathrm{O}_{12}\left(I S=0.34 \mathrm{~mm} \mathrm{~s}^{-1}\right.$ at $\left.298 \mathrm{~K}\right),{ }^{26}$ thus the iron valence is close to +3.75 at this temperature for all. A few $\%$ of $\mathrm{Fe}^{3+}$ ions are incorporated into the $A^{\prime}$-site as a doublet with a large 
quadrupole splitting of $\Delta E_{q} \sim 1.8 \mathrm{~mm} \mathrm{~s}^{-1}$, as reported for $A \mathrm{Cu}_{3} \mathrm{Fe}_{4} \mathrm{O}_{12}$ compounds $(A=\mathrm{Ca}, \mathrm{Sr}, \mathrm{Y}){ }^{23-25} \mathrm{For}^{\mathrm{EuCu}} \mathrm{Fe}_{4} \mathrm{O}_{12}$ and $\mathrm{TbCu}_{3} \mathrm{Fe}_{4} \mathrm{O}_{12}$, the primary singlet component transforms into a magnetic sextet with $I S=\sim 0.45 \mathrm{~mm} \mathrm{~s}^{-1}$ in the $4 \mathrm{~K}$ spectra. These $I S$ values are close to that of $\mathrm{LaCu}_{3} \mathrm{Fe}_{4} \mathrm{O}_{12}$ at the lowest temperature $\left(0.47 \mathrm{~mm} \mathrm{~s}^{-1}\right),{ }^{35}$ verifying that the $\mathrm{Fe}^{3+}$ species are generated by CT transitions in $\mathrm{EuCu}_{3} \mathrm{Fe}_{4} \mathrm{O}_{12}$ and $\mathrm{TbCu}_{3} \mathrm{Fe}_{4} \mathrm{O}_{12}$. This fact allows us to conclude that the $\mathrm{Fe}^{3+}$ valence state is dominant in the low-temperature phases of $L n \mathrm{Cu}_{3} \mathrm{Fe}_{4} \mathrm{O}_{12}(L n=\mathrm{Pr}, \mathrm{Nd}, \mathrm{Sm}, \mathrm{Gd})$. For $\mathrm{DyCu}_{3} \mathrm{Fe}_{4} \mathrm{O}_{12}$ and $\mathrm{LuCu}_{3} \mathrm{Fe}_{4} \mathrm{O}_{12}$, on the other hand, the primary singlet component splits into three magnetic sextets $\left(\mathrm{Fe}^{5+}, \mathrm{Fe}^{3+}(1)\right.$, and $\left.\mathrm{Fe}^{3+}(2)\right)$ in a ratio of $\mathrm{Fe}^{5+}: \mathrm{Fe}^{3+}(1,2)=3: 5$ at $4 \mathrm{~K}$. These transformations are almost identical to that of $\mathrm{YCu}_{3} \mathrm{Fe}_{4} \mathrm{O}_{12}$, ${ }^{25}$ supporting the postulate that $\mathrm{CD}$ transitions of $8 \mathrm{Fe}^{3.75+} \rightarrow 5 \mathrm{Fe}^{3+}+3 \mathrm{Fe}^{5+}$ occur in these compounds. Similar structural and electronic properties (shown later) observed in the intermediate compounds $L n \mathrm{Cu}_{3} \mathrm{Fe}_{4} \mathrm{O}_{12}(\operatorname{Ln}=\mathrm{Ho}, \mathrm{Er}, \mathrm{Tm}, \mathrm{Yb})$ indicate that these compounds also transform to the same electronic states at low temperature. Thus, we confirm that the electronic phase boundary between $\mathrm{CT}$ and $\mathrm{CD}$ phases is between $\mathrm{TbCu}_{3} \mathrm{Fe}_{4} \mathrm{O}_{12}$ and $\mathrm{DyCu}_{3} \mathrm{Fe}_{4} \mathrm{O}_{12}$.

The valence changes of $\mathrm{Cu}$ ions were confirmed by XAS. Figure 4a shows $\mathrm{Cu}-L_{3} \mathrm{XAS}$ spectra for $\operatorname{LnCu} \mathrm{Cu}_{4} \mathrm{O}_{12}$ $(\mathrm{Ln}=\mathrm{La}, \mathrm{Pr}, \mathrm{Nd}, \mathrm{Sm}, \mathrm{Eu}, \mathrm{Gd}, \mathrm{Tb}, \mathrm{Dy})$ collected at $300 \mathrm{~K}$. The XAS spectral shape of $\mathrm{LaCu}_{3} \mathrm{Fe}_{4} \mathrm{O}_{12}$ at $300 \mathrm{~K}$, in which the two main peaks are located at $\sim 930.5$ and $\sim 932.5 \mathrm{eV}$, is similar to that of $\mathrm{LaCu}^{3+} \mathrm{O}_{3},{ }^{36}$ while the single peak at $\sim 930.5 \mathrm{eV}$ observed in $L n \mathrm{Cu}_{3} \mathrm{Fe}_{4} \mathrm{O}_{12}\left(\mathrm{Ln}=\mathrm{Sm}, \mathrm{Eu}, \mathrm{Gd}, \mathrm{Tb}\right.$, Dy) at $300 \mathrm{~K}$ is similar to those of $\mathrm{Cu}^{2+}$-oxides. ${ }^{37} \mathrm{For} \mathrm{PrCu}_{3} \mathrm{Fe}_{4} \mathrm{O}_{12}$, the XAS spectrum has a complicated structure because of overlapping $\operatorname{Pr}-M_{5}$ absorption. We can see shoulder peaks at $\sim 932.5$ $\mathrm{eV}$ in $\mathrm{PrCu}_{3} \mathrm{Fe}_{4} \mathrm{O}_{12}$ and $\mathrm{NdCu}_{3} \mathrm{Fe}_{4} \mathrm{O}_{12} \mathrm{XAS}$ data, in addition to the main peak at $\sim 930.5 \mathrm{eV}$. These shoulder peaks derive from a certain fraction of $\mathrm{Cu}^{3+}$ ions in these compounds because of the coexistence of $\operatorname{Ln}^{3+} \mathrm{Cu}_{3}^{2+} \mathrm{Fe}^{3.75+} \mathrm{O}_{12}$ and $\mathrm{Ln}^{3+} \mathrm{Cu}_{3}^{3+} \mathrm{Fe}^{3+}{ }_{4} \mathrm{O}_{12}$ phases, as displayed in the XRD patterns (see Figure $\mathrm{S} 2$ in the Supporting Information). The XAS 
spectra of $L n \mathrm{Cu}_{3} \mathrm{Fe}_{4} \mathrm{O}_{12}(\mathrm{Ln}=\mathrm{Pr}, \mathrm{Nd}, \mathrm{Sm}, \mathrm{Eu}, \mathrm{Gd}, \mathrm{Tb})$ at $100 \mathrm{~K}$ show double peaks at $\sim 930.5$ and $\sim 932.5 \mathrm{eV}$ (see Figure 4b). This confirms that the $\mathrm{Cu}^{3+}$ valence states are dominant in these compounds. On the other hand, the XAS spectral shape of $\mathrm{DyCu}_{3} \mathrm{Fe}_{4} \mathrm{O}_{12}$ is unchanged down to $100 \mathrm{~K}$, exhibiting that the $\mathrm{Cu}^{2+}$ valence state is retained at this temperature. These results demonstrate that the $\mathrm{Cu}$ valence changes from divalent to trivalent at the $\mathrm{CT}$ transition for $\operatorname{Ln} \mathrm{Cu}_{3} \mathrm{Fe}_{4} \mathrm{O}_{12}(\operatorname{Ln}$ $=\mathrm{La}, \mathrm{Pr}, \mathrm{Nd}, \mathrm{Sm}, \mathrm{Eu}, \mathrm{Gd}, \mathrm{Tb})$, whereas the $\mathrm{Cu}^{2+}$ state is maintained for the charge-disproportionated $\mathrm{DyCu}_{3} \mathrm{Fe}_{4} \mathrm{O}_{12}$ phase .

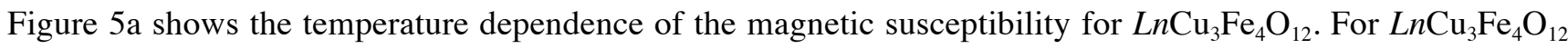
$(\mathrm{Ln}=\mathrm{La}, \mathrm{Pr}, \mathrm{Nd}, \mathrm{Sm}, \mathrm{Eu}, \mathrm{Gd}, \mathrm{Tb})$, antiferromagnetic transitions are observed. The Néel temperature $\left(T_{\mathrm{N}}\right)$ systematically decreases from $367 \mathrm{~K}(\mathrm{La})$ to $233 \mathrm{~K}(\mathrm{~Tb})$ with decreasing $r_{L n}$, which corresponds to the evolution of the CT transition temperature as shown in the XRD data (Figure 2c). On the other hand, $L n \mathrm{Cu}_{3} \mathrm{Fe}_{4} \mathrm{O}_{12}(\mathrm{Ln}=\mathrm{Dy}, \mathrm{Ho}, \mathrm{Er}, \mathrm{Tm}, \mathrm{Yb}, \mathrm{Lu})$ exhibit ferromagnetic transitions at almost identical Curie temperatures $\left(T_{\mathrm{C}}\right)$ of $\sim 250-260 \mathrm{~K}$. These values are close to $T_{\mathrm{C}}$

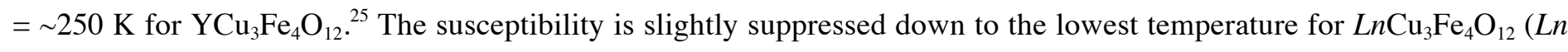
$=\mathrm{Dy}, \mathrm{Ho}, \mathrm{Er})$, which most likely originates from the $4 \mathrm{f}$ magnetic moments of the $\mathrm{Ln}$ ions making an antiparallel alignment with the $\mathrm{Fe}$ spins in low magnetic fields, in analogy with magnetic structures of ferrimagnetic $\operatorname{Ln} \mathrm{Cu}_{3} \mathrm{Mn}_{4} \mathrm{O}_{12}$

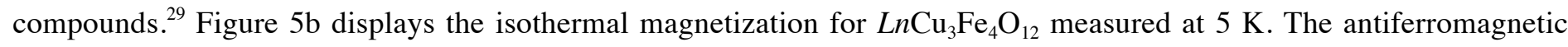
compounds ( $\mathrm{Ln}=\mathrm{La}, \mathrm{Pr}, \mathrm{Nd}, \mathrm{Sm}, \mathrm{Eu}, \mathrm{Gd}, \mathrm{Tb})$ show no sign of spontaneous magnetization, whereas the ferromagnetic compounds $(L n=\mathrm{Dy}, \mathrm{Ho}, \mathrm{Er}, \mathrm{Tm}, \mathrm{Yb}, \mathrm{Lu})$ exhibit soft ferromagnetic behavior. $\mathrm{LuCu}_{3} \mathrm{Fe}_{4} \mathrm{O}_{12}$ has no $4 \mathrm{f}$ magnetic moment because of the $4 \mathrm{f}^{14}$ electron configuration, displaying a saturation magnetization of $\sim 7.6 \mu_{\mathrm{B}}$ per formula unit. This value is identical to that of $\mathrm{YCu}_{3} \mathrm{Fe}_{4} \mathrm{O}_{12}\left(7.6 \mu_{\mathrm{B}}\right),{ }^{25}$ suggesting that $\mathrm{LuCu}_{3} \mathrm{Fe}_{4} \mathrm{O}_{12}$ has the same magnetic structure (ferrimagnetic, $\left.\mathrm{Cu}^{2+} \downarrow-\mathrm{Fe}^{5+} \uparrow-\mathrm{Fe}^{3+}(1) \uparrow-\mathrm{Fe}^{3+}(2) \downarrow\right)$ as $\mathrm{YCu}_{3} \mathrm{Fe}_{4} \mathrm{O}_{12}$. For other ferromagnetic compounds (Ln = Dy, Ho, Er, Tm, Yb), 
magnetization curves are complicated because of the contribution of the $4 \mathrm{f}$ magnetic moments. However, since antiparallel couplings between $\mathrm{Cu}$ and $\mathrm{Fe}$ are confirmed in MCD spectra (Figure S5 in the Supporting Information), their magnetic structures as concerns the $\mathrm{Cu}$ and $\mathrm{Fe}$ spins are considered to be identical to that of $\mathrm{LuCu}_{3} \mathrm{Fe}_{4} \mathrm{O}_{12}$.

Figure 6 shows the temperature dependence of the electrical resistivity for $L n \mathrm{Cu}_{3} \mathrm{Fe}_{4} \mathrm{O}_{12}$. Metal-to-insulator transitions are observed at temperatures between 220 and $360 \mathrm{~K}$ for $L n \mathrm{Cu}_{3} \mathrm{Fe}_{4} \mathrm{O}_{12}(\mathrm{Ln}=\mathrm{La}, \mathrm{Pr}, \mathrm{Nd}, \mathrm{Sm}, \mathrm{Eu}, \mathrm{Gd}, \mathrm{Tb})$, in which very small temperature dependences of high-temperature metallic phases change into insulator-like large dependences below the CT transition temperature, as reported for $\mathrm{LaCu}_{3} \mathrm{Fe}_{4} \mathrm{O}_{12}{ }^{26}$ In contrast, metal-to-semiconductor transitions are observed for $L n \mathrm{Cu}_{3} \mathrm{Fe}_{4} \mathrm{O}_{12}(L n=\mathrm{Dy}, \mathrm{Ho}, \mathrm{Er}, \mathrm{Tm}, \mathrm{Yb}, \mathrm{Lu}$ ) below $\sim 220 \mathrm{~K}$ (Figure 6b), which are similar to that of $\mathrm{YCu}_{3} \mathrm{Fe}_{4} \mathrm{O}_{12}$ accompanying $\mathrm{CD}$ transition. The temperature dependences of the resistivity in the charge-disproportionated phases are much smaller than those in the charge-transferred phases. The inset of Figure 6a shows that a large thermal hysteresis exists in the CT transitions due to their first-order characteristics, while the thermal hysteresis in the CD transitions is negligibly small (see the inset of Figure 6b).

The above analysis of crystal structure, valence states, and physical properties of $L n \mathrm{Cu}_{3} \mathrm{Fe}_{4} \mathrm{O}_{12}$ divides these compounds into two classes, in which the first class arouses a CT transition like that of $\mathrm{LaCu}_{3} \mathrm{Fe}_{4} \mathrm{O}_{12}$, and the other class generates a $\mathrm{CD}$ transition like that of $\mathrm{YCu}_{3} \mathrm{Fe}_{4} \mathrm{O}_{12}$. In a previous report, ${ }^{25}$ we investigated the origin of the alternative electronic phase transitions in $A^{3+} \mathrm{Cu}_{3} \mathrm{Fe}_{4} \mathrm{O}_{12}$ perovskites, concluding that the $\mathrm{CT}$ transition predominantly occurs in $\mathrm{LaCu}_{3} \mathrm{Fe}_{4} \mathrm{O}_{12}$ to relieve the bond strains represented as overbonding (underbonding) in the $\mathrm{La}-\mathrm{O}$ ( $\mathrm{Fe}-\mathrm{O}$ ) bond, while the $\mathrm{CD}$ transition occurs in $\mathrm{YCu}_{3} \mathrm{Fe}_{4} \mathrm{O}_{12}$ because the opposite kind of bond strains, which are dominant in $\mathrm{YCu}_{3} \mathrm{Fe}_{4} \mathrm{O}_{12}$, are not necessarily relaxed by the $\mathrm{CT}$ transition. Here, we attempt to make further refinements to the above conclusions based on 
the structural data of $L n \mathrm{Cu}_{3} \mathrm{Fe}_{4} \mathrm{O}_{12}$. Figure 7a shows selected bond lengths and bond angle versus ionic radius of $L n$ ions for the $\mathrm{Ln}^{3+} \mathrm{Cu}^{2+}{ }_{3} \mathrm{Fe}^{3.75+}{ }_{4} \mathrm{O}_{12}$ phase in the vicinity of room temperature. The $\mathrm{Ln}-\mathrm{O}$ bond shrinks almost monotonically as the $r_{L n}$ decreases. The $\mathrm{Fe}-\mathrm{O}$ bond shrinks correspondingly, while the $\mathrm{Cu}-\mathrm{O}$ bond length is almost constant. This is because the larger $L n$ ions expand the unit cell volumes and the $\mathrm{Fe}-\mathrm{O}$ bonds are accordingly stretched in the relationship $a=4 l_{\mathrm{Fe}-\mathrm{O}} \times$ $\sin (\psi / 2)$, where $a$ is the lattice constant, $l_{\mathrm{Fe}-\mathrm{O}}$ is the $\mathrm{Fe}-\mathrm{O}$ bond length, and $\psi$ is the $\mathrm{Fe}-\mathrm{O}-\mathrm{Fe}$ bond angle. The $\mathrm{Fe}-\mathrm{O}-\mathrm{Fe}$ bond angle slightly increases with decreasing $r_{L n}$, which is attributed to the decrement in the difference in ionic radii between $A$-site $\left(r_{A}\right)$ and $A^{\prime}$-site $\left(r_{A^{\prime}}\right)$ ions, $\Delta r_{\mathrm{A}}\left(\Delta r_{\mathrm{A}}=r_{A}-r_{A^{\prime}}\right)$, as demonstrated in our previous paper. ${ }^{38}$ When $\Delta r_{\mathrm{A}}$ decreases from $0.59 \AA$ (La) to $0.407 \AA(\mathrm{Lu})$, the Fe-O-Fe bond angle is seen to increase from 139.2 to $140.3^{\circ}$.

The BVS analysis unveils the delicate relationship between $L n-\mathrm{O}$ and $\mathrm{Fe}-\mathrm{O}$ bonds. Figure $7 \mathrm{~b}$ shows the BVS, bond discrepancy, and GII in the valence unit (v.u.) as a function of $r_{L n}$ for the $\mathrm{Ln}^{3+} \mathrm{Cu}^{2+}{ }_{3} \mathrm{Fe}^{3.75+}{ }_{4} \mathrm{O}_{12}$ phase. The BVS of Cu is close to the expected value $(+2)$ for all of the compounds, indicating that the $\mathrm{Cu}-\mathrm{O}$ bond remains in a proper state. On the other hand, the BVS of $L n$ drastically decreases from $+3.60(\mathrm{La})$ to $+2.61(\mathrm{Lu})$ while the BVS of Fe increases from $+3.47(\mathrm{La})$ to $+3.80(\mathrm{Lu})$. Deviations of the BVS from the nominal ionic valences are represented as overbonding or underbonding in the relevant bonds. The overbonding (underbonding) in the $L n-\mathrm{O}(\mathrm{Fe}-\mathrm{O})$ bond is enhanced from $\mathrm{DyCu}_{3} \mathrm{Fe}_{4} \mathrm{O}_{12}$ to $\mathrm{LaCu}_{3} \mathrm{Fe}_{4} \mathrm{O}_{12}$. In contrast, the underbonding (overbonding) in the $\mathrm{Ln}-\mathrm{O}(\mathrm{Fe}-\mathrm{O})$ bond is enhanced from $\mathrm{DyCu}_{3} \mathrm{Fe}_{4} \mathrm{O}_{12}$ to $\mathrm{LuCu}_{3} \mathrm{Fe}_{4} \mathrm{O}_{12}$. These trends are considered to be the result of bond strains, which represent structural instability. The instability of each bond is evaluated by the bond discrepancy, $d_{M}$, which is defined as $d_{M}=\operatorname{BVS}(M)-V_{M}$, where $\mathrm{BVS}(M)$ and $V_{M}$ are the BVS and ionic valence of the $M$ ion, respectively. The total instability of the structure is evaluated by GII, which is defined as GII $=\left[\Sigma_{M}\left(d_{M}{ }^{2}\right) / N\right]^{1 / 2}$, where $N$ is the number of atoms in the formula unit. When the 
GII increases, the relevant structure becomes unstable. The GII displays a quadric-like dependence on $r_{L n}$ with the

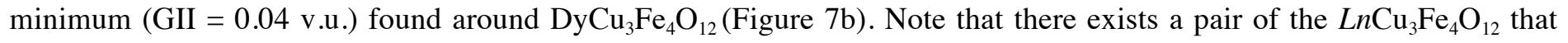
have almost the same GII values at the La- and Lu-sides (i.e. GII $=0.06$ v.u. for $\mathrm{EuCu}_{3} \mathrm{Fe}_{4} \mathrm{O}_{12}$ and $\mathrm{TmCu}_{3} \mathrm{Fe}_{4} \mathrm{O}_{12}, \mathrm{GII}=$ 0.10 v.u. for $\mathrm{NdCu}_{3} \mathrm{Fe}_{4} \mathrm{O}_{12}$ and $\mathrm{LuCu}_{3} \mathrm{Fe}_{4} \mathrm{O}_{12}$ ), but the members of this pair transform into opposite types of the electronic phases $(\mathrm{CT}$ or $\mathrm{CD})$. A further notable feature is that the $\mathrm{CT}$ transition temperature is strongly dependent upon the GII

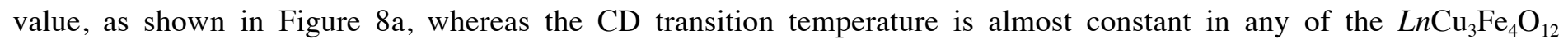
compounds. This suggests that the thermodynamic stability of the high-temperature $\mathrm{Ln}^{3+} \mathrm{Cu}^{2+}{ }_{3} \mathrm{Fe}^{3.75+}{ }_{4} \mathrm{O}_{12}$ phase is sensitive to the bond strains in the case of the CT transitions. In-depth bond strain analysis is conducted in a diagram of $d_{L n}$ versus $d_{\mathrm{Fe}}$ (Figure 8b). $\mathrm{DyCu}_{3} \mathrm{Fe}_{4} \mathrm{O}_{12}$ is located at the nearest point to the origin, indicating that this compound has the least

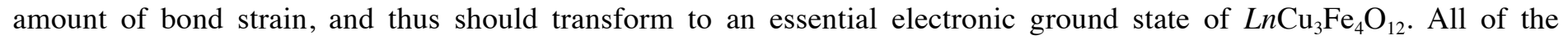
compounds that generate CT transitions ( $L n=\mathrm{La}, \mathrm{Pr}, \mathrm{Nd}, \mathrm{Sm}, \mathrm{Eu}, \mathrm{Gd}, \mathrm{Tb})$ are found in the second quadrant $\left(d_{L n} \geqq 0\right.$ and $\left.d_{\mathrm{Fe}} \leqq 0\right)$, while those arousing CD transitions ( $\left.L n=\mathrm{Dy}, \mathrm{Ho}, \mathrm{Er}, \mathrm{Tm}, \mathrm{Yb}, \mathrm{Lu}\right)$ are in the fourth quadrant $\left(d_{L n} \leqq 0\right.$ and $d_{\mathrm{Fe}} \geqq$ 0 ). The vacancy existing in the first and third quadrants demonstrates that the $L n-\mathrm{O}$ and $\mathrm{Fe}-\mathrm{O}$ bonds tightly correlate to each other. Specifically, larger $L n$ ions expand the unit cell volume and stretch the Fe-O bond with the elongation of the Ln-O bond constrained by the rigid Fe-O framework, while smaller Ln ions contract the unit cell and shrink the Fe-O bond, which is limited by the robustness of the $\mathrm{Fe}-\mathrm{O}$ bond. This proves that a small difference in the type of bond strain may switch the electronic phase transitions precisely. This is a remarkable example of the structural instabilities being categorized by bond discrepancy.

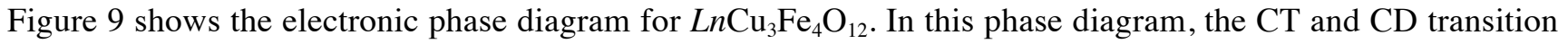


temperatures are plotted as a function of $r_{L n}$. At high temperature, the paramagnetic metallic phase (PM-M) is dominant for all. $L n \mathrm{Cu}_{3} \mathrm{Fe}_{4} \mathrm{O}_{12}$ with larger $L n$ ions $(L n=\mathrm{La}, \mathrm{Pr}, \mathrm{Nd}, \mathrm{Sm}, \mathrm{Eu}, \mathrm{Gd}, \mathrm{Tb})$ transform to charge-transferred, antiferromagnetic, and insulating phase (AFM-I), in which the transition temperature decreases with the $L n$ ion radius. In contrast, $L n \mathrm{Cu}_{3} \mathrm{Fe}_{4} \mathrm{O}_{12}$ with smaller $L n$ ions $(L n=\mathrm{Dy}, \mathrm{Ho}, \mathrm{Er}, \mathrm{Tm}, \mathrm{Yb}, \mathrm{Lu})$ transform to the charge-disproportionated, ferrimagnetic, and semiconducting phase (FerriM-S), in which the transition temperatures are almost constant. The electronic phase boundary between AFM-I and FerriM-S is located between $\mathrm{TbCu}_{3} \mathrm{Fe}_{4} \mathrm{O}_{12}$ and $\mathrm{DyCu}_{3} \mathrm{Fe}_{4} \mathrm{O}_{12}$. This boundary may be interpreted as the "zero-point" of the bond strains, in which no strains are included in any metal-oxygen bonds. This is in sharp contrast to the electronic phase diagram of $\mathrm{Ca}_{1-x} \mathrm{La}_{x} \mathrm{Cu}_{3} \mathrm{Fe}_{4} \mathrm{O}_{12}$ proposed by $\mathrm{Chen}^{39}$ In the $\mathrm{Ca}_{1-}$ ${ }_{x} \mathrm{La}_{x} \mathrm{Cu}_{3} \mathrm{Fe}_{4} \mathrm{O}_{12}$ phase diagram, neither local structures nor bond strains were considered, whereas carrier concentration was treated as a primary parameter. In addition, electronic phase separations are unavoidable in a wide range of intermediate compositions. However, our present study successfully reveals that bond strains predominantly control electronic phase transitions of $L n \mathrm{Cu}_{3} \mathrm{Fe}_{4} \mathrm{O}_{12}$ and a clear phase boundary is defined. Therefore, our results enable precise tuning of electronic phases by bond strains, instead of by carrier concentration.

\section{CONCLUSIONS}

We investigated low-temperature electronic phases of $L n \mathrm{Cu}_{3} \mathrm{Fe}_{4} \mathrm{O}_{12}$ ( $L n$ : lanthanide) perovskites. All of the compounds are in an identical valence state of $\mathrm{Ln}^{3+} \mathrm{Cu}^{2+}{ }_{3} \mathrm{Fe}^{3.75+}{ }_{4} \mathrm{O}_{12}$ at high temperature. The compounds with larger $L n$ ions $(\mathrm{Ln}=\mathrm{La}, \mathrm{Pr}, \mathrm{Nd}, \mathrm{Sm}, \mathrm{Eu}, \mathrm{Gd}, \mathrm{Tb})$ induce an intersite charge transfer $\left(3 \mathrm{Cu}^{2+}+4 \mathrm{Fe}^{3.75+} \rightarrow 3 \mathrm{Cu}^{3+}+4 \mathrm{Fe}^{3+}\right)$ at temperatures between 240 and $360 \mathrm{~K}$, whereas all compounds with smaller Ln ions $(\mathrm{Ln}=\mathrm{Dy}, \mathrm{Ho}, \mathrm{Er}, \mathrm{Tm} \mathrm{Yb}, \mathrm{Lu})$ 
generate a charge disproportionation $\left(8 \mathrm{Fe}^{3.75+} \rightarrow 5 \mathrm{Fe}^{3+}+3 \mathrm{Fe}^{5+}\right)$ below $\sim 250-260 \mathrm{~K}$. The former series exhibits metal-to-insulator, antiferromagnetic, and isostructural volume expansion transitions simultaneously with the intersite charge transfer. In contrast, the latter shows metal-to-semiconductor, ferrimagnetic, and charge ordering transitions simultaneously with the charge disproportionation. Structural instability of $L n \mathrm{Cu}_{3} \mathrm{Fe}_{4} \mathrm{O}_{12}$ as estimated from the bond discrepancies and global instability indices demonstrate that the bond strains in these compounds are distinguished into two types, which are well illustrated in a bond strain diagram. The first type is overbonding in the $L n-\mathrm{O}$ bond and underbonding in the $\mathrm{Fe}-\mathrm{O}$ bond, while the other type is the opposite. Intersite charge transfer transition temperatures are dependent upon the global instability indices, whereas those of the charge disproportionation transition are almost identical regardless of the magnitude of structural instability. Our bond strain analysis demonstrates that the bond strains may control the electronic phase transitions precisely.

\section{ASSOCIATED CONTENT}

Supporting Information. XRD patterns, SXRD patterns, ED patterns, MCD spectra, and crystallographic data (CIF) for $L n \mathrm{Cu}_{3} \mathrm{Fe}_{4} \mathrm{O}_{12}$. This material is available free of charge via the Internet at http://pubs.acs.org.

\section{AUTHOR INFORMATION}

\section{Corresponding Author}

i-yamada@21c.osakafu-u.ac.jp 


\section{Present Address}

${ }^{\dagger}$ Deutsches Elektronen Synchrotron (DESY), 22607 Hamburg, Germany

\section{Notes}

The authors declare no competing financial interest.

\section{ACKNOWLEDGEMENTS}

We thank Shintaro Ishiwata for helpful discussion, and Hiroshi Kageyama, Minoru Nohara, and Kensuke Konishi for support in the acquisition of magnetization data. We also thank Shigeki Mori for preliminary measurements of temperature-variable XRD patterns. The synchrotron radiation experiments were performed at SPring-8 with the approval of JASRI (Proposal Nos. 2010B1707, 2011A1047, 2012A1002, 2012A1619, 2013A1042, 2013A1043, and 2013A1689).

Parts of this work were performed using the facilities of ISSP. This work was partially supported by the Murata Science Foundation. 


\section{REFERENCES}

(1) Imada, M.; Fujimori, A.; Tokura, Y.Rev. Mod. Phys. 1998, 70, 1039.

(2) Brown, I. D.; Altermatt, D. Acta Crystallogr. B 1985, 41, 244.

(3) Brown, I. D. Chem. Rev. 2009, 109, 6858.

(4) Lufaso, M. W.; Woodward, P. M. Acta Crystallogr. B 2001, 57, 725.

(5) Alonso, J. A.; Martinez-Lope, M. J.; de la Calle, C.; Pomjakushin, V. J. Mater. Chem. 2006, 16, 1555.

(6) Zhang, H.; Li, N.; Li, K.; Xue, D. F. Acta Crystallogr. B 2007, 63, 812.

(7) MacChesney, J. B.; Sherwood, R. C.; Potter, J. F. J. Chem. Phys. 1965, 43, 1907.

(8) Takeda, T.; Yamaguchi, Y.; Watanabe, H. J. Phys. Soc. Jpn. 1972, 4, 967.

(9) Ishiwata, S.; Tokunaga, M.; Kaneko, Y.; Okuyama, D.; Tokunaga, Y.; Wakimoto, S.; Kakurai, K.; Arima, T.;

Taguchi, Y.; Tokura, Y. Phys. Rev. B 2011, 84.

(10) Bocquet, A. E.; Fujimori, A.; Mizokawa, T.; Saitoh, T.; Namatame, H.; Suga, S.; Kimizuka, N.; Takeda, Y.; Takano, M. Phys. Rev. B 1992, 45, 1561.

(11) Bocquet, A. E.; Mizokawa, T.; Saitoh, T.; Namatame, H.; Fujimori, A. Phys. Rev. B 1992, 46, 3771.

(12) Takano, M.; Nakanishi, N.; Takeda, Y.; Naka, S.; Takada, T. Mater. Res. Bull. 1977, 12, 923.

(13) Mostovoy, M. Phys. Rev. Lett. 2005, 94.

(14) Hayashi, N.; Yamamoto, T.; Kageyama, H.; Nishi, M.; Watanabe, Y.; Kawakami, T.; Matsushita, Y.; Fujimori, A.;

Takano, M. Angew. Chem., Int. Ed. 2011, 50, 12547.

(15) Li, Z.; Laskowski, R.; Iitaka, T.; Tohyama, T. Phys. Rev. B 2012, 85.

(16) Alonso, J. A.; Sanchez-Benitez, J.; De Andres, A.; Martinez-Lope, M. J.; Casais, M. T.; Martinez, J. L. Appl. Phys.

Lett. 2003, 83, 2623.

(17) Zeng, Z.; Greenblatt, M.; Subramanian, M. A.; Croft, M. Phys. Rev. Lett. 1999, 82, 3164.

(18) Kobayashi, W.; Terasaki, I.; Takeya, J.; Tsukada, I.; Ando, Y. J. Phys. Soc. Jpn. 2004, 73, 2373.

(19) Prodi, A.; Gilioli, E.; Gauzzi, A.; Licci, F.; Marezio, M.; Bolzoni, F.; Huang, Q.; Santoro, A.; Lynn, J. W. Nature Mater. 2004, 3, 48 . 
(20) Subramanian, M. A.; Li, D.; Duan, N.; Reisner, B. A.; Sleight, A. W. J. Solid State Chem. 2000, 151, 323.

(21) Akizuki, Y.; Yamada, I.; Fujita, K.; Nishiyama, N.; Irifune, T.; Yajima, T.; Kageyama, H.; Tanaka, K. Inorg. Chem. 2013, 52, 11538..

(22) Ovsyannikov, S. V.; Abakumov, A. M.; Tsirlin, A. A.; Schnelle, W.; Egoavil, R.; Verbeeck, J.; Van Tendeloo, G.; Glazyrin, K. V.; Hanfland, M.; Dubrovinsky, L. Angew. Chem., Int. Ed. 2013, 52, 1494.

(23) Yamada, I.; Takata, K.; Hayashi, N.; Shinohara, S.; Azuma, M.; Mori, S.; Muranaka, S.; Shimakawa, Y.; Takano, M. Angew. Chem., Int. Ed. 2008, 47, 7032 .

(24) Yamada, I.; Tsuchida, K.; Ohgushi, K.; Hayashi, N.; Kim, J.; Tsuji, N.; Takahashi, R.; Matsushita, M.; Nishiyama, N.; Inoue, T.; Irifune, T.; Kato, K.; Takata, M.; Takano, M. Angew. Chem., Int. Ed. 2011, 50, 6579.

(25) Etani, H.; Yamada, I.; Ohgushi, K.; Hayashi, N.; Kusano, Y.; Mizumaki, M.; Kim, J.; Tsuji, N.; Takahashi, R.;

Nishiyama, N.; Inoue, T.; Irifune, T.; Takano, M. J. Am. Chem. Soc. 2013, 135, 6100.

(26) Long, Y. W.; Hayashi, N.; Saito, T.; Azuma, M.; Muranaka, S.; Shimakawa, Y. Nature 2009, 458, 60.

(27) Long, Y. W.; Saito, T.; Tohyama, T.; Oka, K.; Azuma, M.; Shimakawa, Y. Inorg. Chem. 2009, 48, 8489.

(28) Dittl, A.; Krohns, S.; Sebald, J.; Schrettle, F.; Hemmida, M.; von Nidda, H. A. K.; Riegg, S.; Reller, A.; Ebbinghaus, S. G.; Loidl, A. Euro. Phys. J. B 2011, 79, 391.

(29) Sanchez-Benitez, J.; Alonso, J. A.; Falcon, H.; Martinez-Lope, M. J.; De Andres, A.; Fernandez-Diaz, M. T. J. Phys. Condensed Matter 2005, 17, S3063.

(30) Brown, I. D.; The Chemical Bond in Inorganic Chemistry; Oxford University Press: Oxford, UK, 2001.

(31) Shannon, R. D. Acta Crystallogr. A 1976, 32, 751.

(32) Kakihana, M. J. Sol-Gel Sci.Technol. 1996, 6, 7.

(33) Izumi, F.; Momma, K. Solid State Phenom. 2007, 130, 15.

(34) Momma, K.; Izumi, F. J. Appl. Crystallogr. 2011, 44, 1272.

(35) Long, Y. W.; Shimakawa, Y. New J. Phys. 2010, 12.

(36) Mizokawa, T.; Fujimori, A.; Namatame, H.; Takeda, Y.; Takano, M. Phys. Rev. B 1998, 57, 9550.

(37) McGuinness, C.; Downes, J. E.; Sheridan, P.; Glans, P. A.; Smith, K. E.; Si, W.; Johnson, P. D. Phys. Rev. B 2005, 
71.

(38) Shiro, K.; Yamada, I.; Ikeda, N.; Ohgushi, K.; Mizumaki, M.; Takahashi, R.; Nishiyama, N.; Inoue, T.; Irifune, T. Inorg. Chem. 2013, 52, 1604.

(39) Chen, W.; Saito, T.; Hayashi, N.; Takano, M.; Shimakawa, Y. Sci. Rep. 2012, 2, 449.

(40) Woodward, P. M.; Cox, D. E.; Moshopoulou, E.; Sleight, A. W.; Morimoto, S. Phys. Rev. B 2000, $62,844$.

(41) Kanowitz, S. M.; Palenik, G. J. Inorg. Chem. 1998, 37, 2086. 


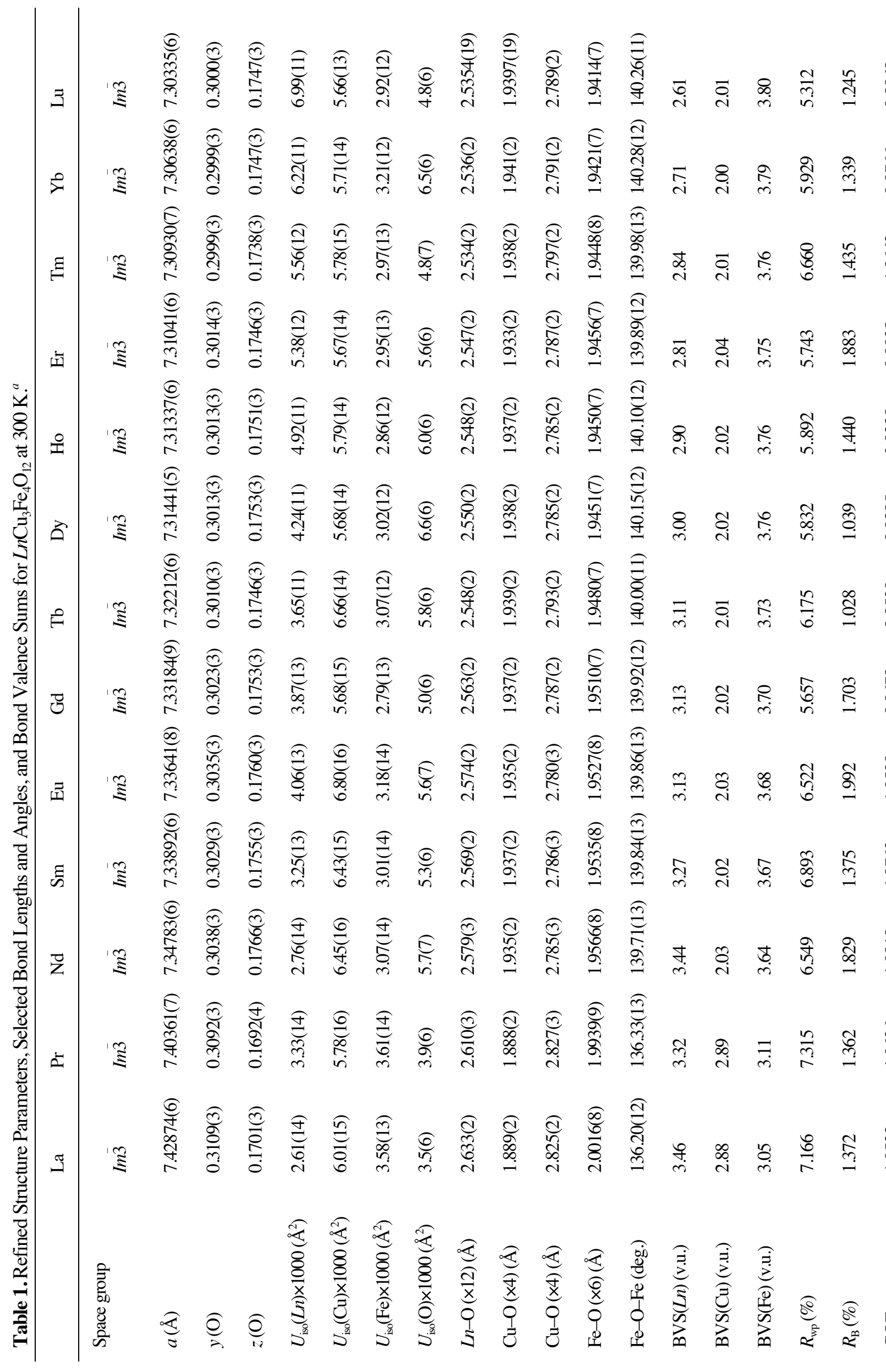




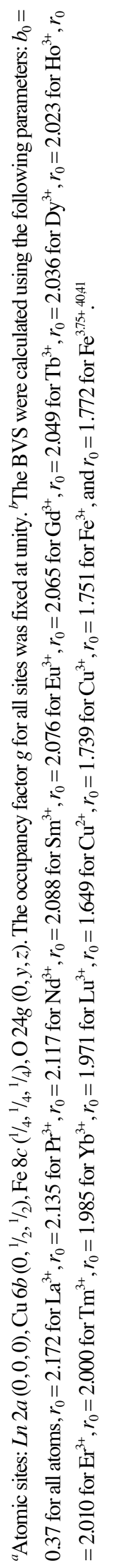




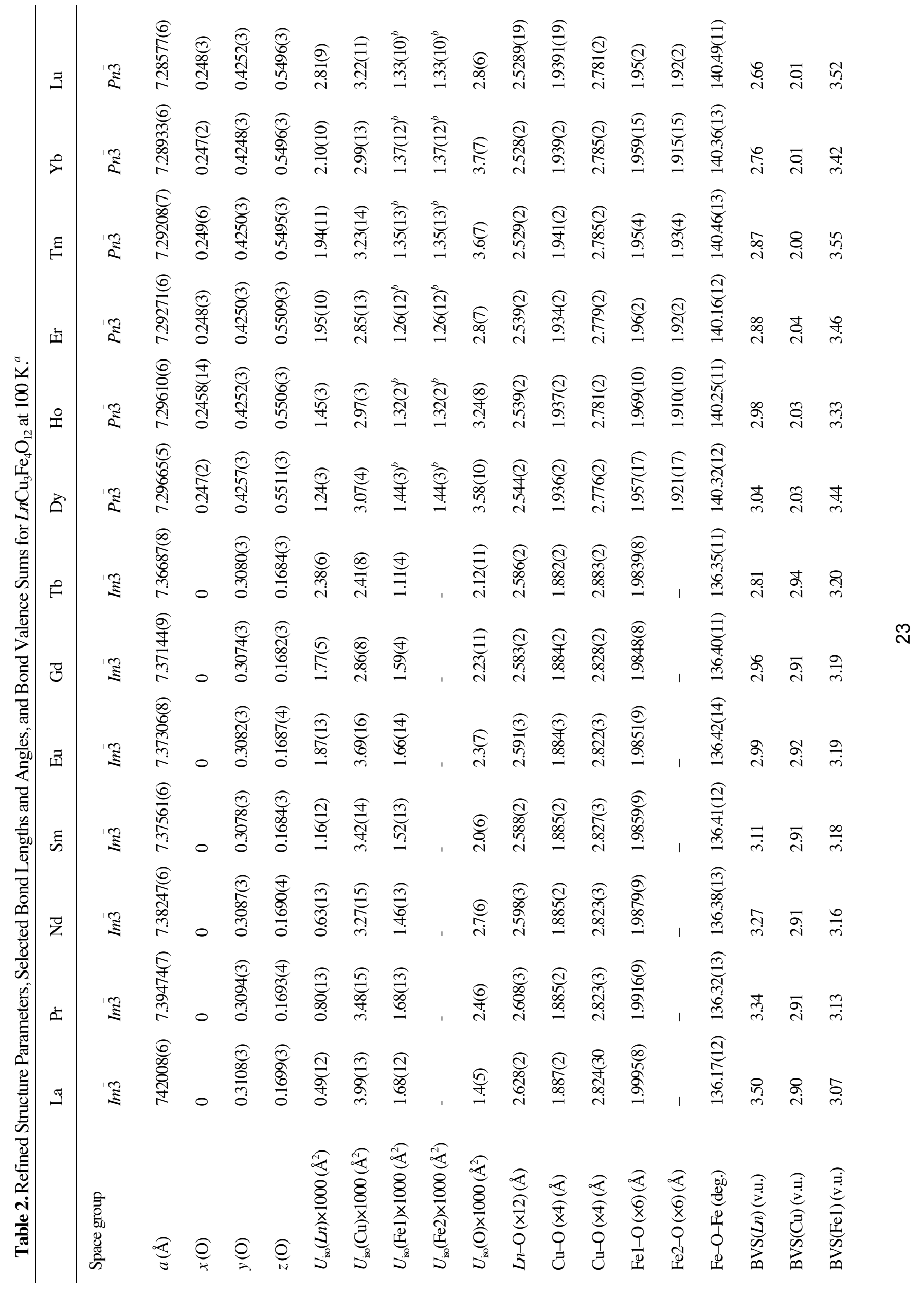




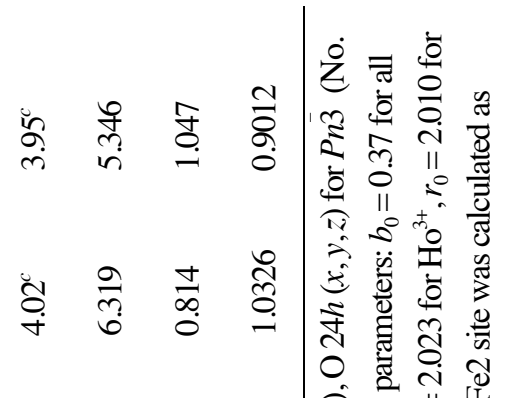

$$
\begin{aligned}
& \text { ¿. } \\
& \text { 究 }
\end{aligned}
$$

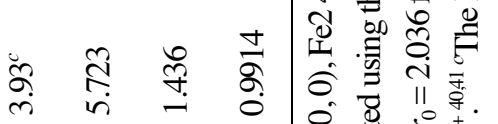

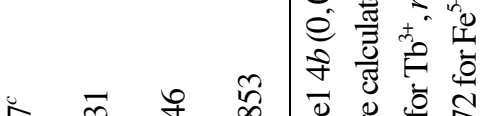

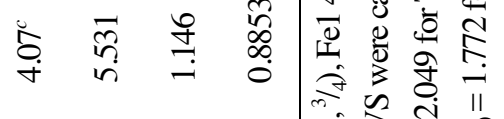

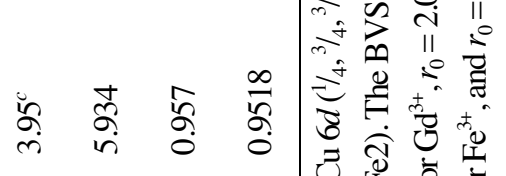

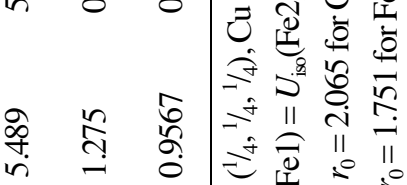

$$
\begin{aligned}
& \text { 每 }
\end{aligned}
$$

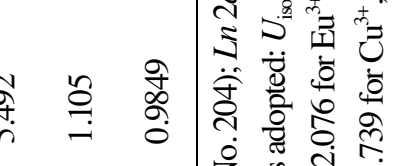

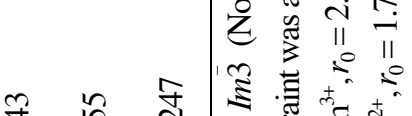

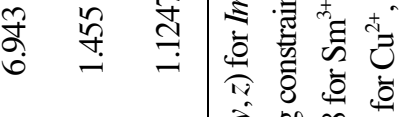

$$
\begin{aligned}
& \text { बे है }
\end{aligned}
$$

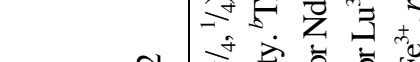

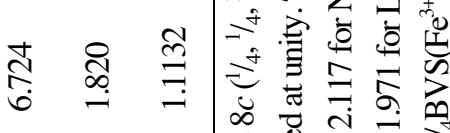

$$
\begin{aligned}
& \text { 促 } \\
& \text { กิ तิ } \\
& \text { e }
\end{aligned}
$$

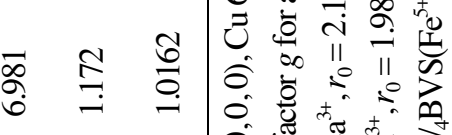

$$
\begin{aligned}
& \text { e }
\end{aligned}
$$

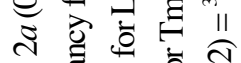

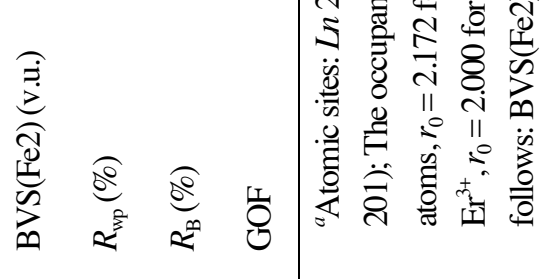


Table 3. Hyperfine Parameters for $L n \mathrm{Cu}_{3} \mathrm{Fe}_{4} \mathrm{O}_{12}(L n=\mathrm{Eu}, \mathrm{Tb}$, Dy, and $\mathrm{Lu})$ at Room Temperature (RT) anc from Mössbauer Spectra.

\begin{tabular}{|c|c|c|c|c|c|}
\hline & & \multirow{2}{*}{$\mathrm{EuCu}_{3} \mathrm{Fe}_{4} \mathrm{O}_{12}$} & \multicolumn{3}{|c|}{$\mathrm{TbCu}_{3} \mathrm{Fe}_{4} \mathrm{O}_{12} \mathrm{DyCu}_{3} \mathrm{Fe}_{4} \mathrm{O}_{12} \mathrm{LuCu}_{3} \mathrm{Fe}_{4} \mathrm{O}_{12}$} \\
\hline & & & & & \\
\hline \multirow[t]{4}{*}{ (1) $B-\mathrm{Fe}$} & $I S / \mathrm{mm} \mathrm{s}^{-1}$ & 0.18 & 0.18 & 0.17 & 0.16 \\
\hline & $H F / \mathrm{kOe}$ & 0 & 0 & 0 & 0 \\
\hline & $\Delta E_{q} / \mathrm{mm} \mathrm{s}^{-1}$ & 0 & 0 & 0 & 0 \\
\hline & Atomic ratio $(\%)$ & 95 & 97 & 96 & 99 \\
\hline \multirow[t]{4}{*}{ (2) $A^{\prime}-\mathrm{Fe}$} & $I S / \mathrm{mm} \mathrm{s}^{-1}$ & 0.42 & 0.39 & 0.42 & 0.38 \\
\hline & $H F / \mathrm{kOe}$ & 0 & 0 & 0 & 0 \\
\hline & $\Delta E_{q} / \mathrm{mm} \mathrm{s}^{-1}$ & 1.77 & 1.77 & 1.78 & 1.71 \\
\hline & Atomic ratio (\%) & 5 & 3 & 4 & 1 \\
\hline \multicolumn{6}{|l|}{$4 \mathrm{~K}$} \\
\hline \multirow[t]{4}{*}{ (1) $\mathrm{Fe}^{3+}$} & $I S / \mathrm{mm} \mathrm{s}^{-1}$ & 0.45 & 0.46 & 0.39 & 0.36 \\
\hline & $H F / \mathrm{kOe}$ & 513 & 543 & 473 & 432 \\
\hline & $\Delta E_{q} / \mathrm{mm} \mathrm{s}^{-1}$ & 0 & 0 & 0 & 0 \\
\hline & Atomic ratio $(\%)$ & 100 & 100 & 52 & 51 \\
\hline \multirow[t]{4}{*}{ (2) $\mathrm{Fe}^{3+}$} & $I S / \mathrm{mm} \mathrm{s}^{-1}$ & - & - & 0.47 & 0.44 \\
\hline & $H F / \mathrm{kOe}$ & - & - & 550 & 504 \\
\hline & $\Delta E_{q} / \mathrm{mm} \mathrm{s}^{-1}$ & - & - & 0 & 0 \\
\hline & Atomic ratio $(\%)$ & - & - & 13 & 14 \\
\hline \multirow[t]{4}{*}{ (3) $\mathrm{Fe}^{5+}$} & $I S / \mathrm{mm} \mathrm{s}^{-1}$ & - & - & 0.03 & 0.05 \\
\hline & $H F / \mathrm{kOe}$ & - & - & 239 & 217 \\
\hline & $\Delta E_{q} / \mathrm{mm} \mathrm{s}^{-1}$ & - & - & 0 & 0 \\
\hline & Atomic ratio (\%) & - & - & 35 & 35 \\
\hline
\end{tabular}




\section{FIGURE CAPTIONS}

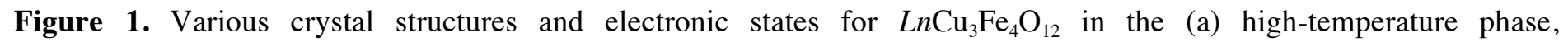
$\mathrm{Ln}^{3+} \mathrm{Cu}^{2+}{ }_{3} \mathrm{Fe}^{3.75+}{ }_{4} \mathrm{O}_{12}(L n=\mathrm{La}-\mathrm{Lu})$; (b) low-temperature charge-transferred phase, $\operatorname{Ln}^{3+} \mathrm{Cu}^{3+}{ }_{3} \mathrm{Fe}^{3+}{ }_{4} \mathrm{O}_{12}(\operatorname{Ln}=\mathrm{La}, \mathrm{Pr}, \mathrm{Nd}, \mathrm{Sm}$, $\mathrm{Eu}, \mathrm{Gd}, \mathrm{Tb}) ;$ and $(\mathrm{c})$ low-temperature charge-disproportionated and charge-ordered phase, $\mathrm{Ln}^{3+} \mathrm{Cu}_{3}^{2+} \mathrm{Fe}^{3+}{ }_{2}\left(\mathrm{Fe}^{5+}{ }_{3 / 4}, \mathrm{Fe}^{3+}{ }_{1 / 4}\right)_{2} \mathrm{O}_{12}(L n=\mathrm{Y}, \mathrm{Dy}, \mathrm{Ho}, \mathrm{Er}, \mathrm{Tm}, \mathrm{Yb}, \mathrm{Lu})$.

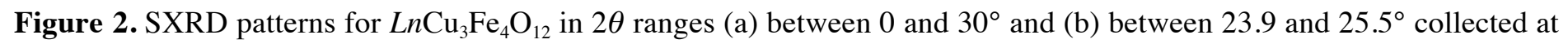
$300 \mathrm{~K}$. Selected $h k l$ reflections are indexed. The wavelength was $0.42085 \AA$. (c) Temperature dependence of $V$ for $L n \mathrm{Cu}_{3} \mathrm{Fe}_{4} \mathrm{O}_{12}$. The data for $L n=\mathrm{La}, \mathrm{Pr}, \mathrm{Nd}, \mathrm{Sm}, \mathrm{Eu}, \mathrm{Gd}, \mathrm{Tb}$, Dy are obtained from XRD, and for $L n=\mathrm{Dy}, \mathrm{Ho}, \mathrm{Er}, \mathrm{Tm}, \mathrm{Yb}$, Lu from SXRD.

Figure 3. Mössbauer spectra of $L n \mathrm{Cu}_{3} \mathrm{Fe}_{4} \mathrm{O}_{12}$ measured at $4 \mathrm{~K}$ and room temperature; $L n=$ (a) Eu, (b) Tb, (c) $\mathrm{Dy}$, (d) $\mathrm{Lu}$. Figure 4. XAS spectra of $\mathrm{Cu}-L_{3}$ edge for $L n \mathrm{Cu}_{3} \mathrm{Fe}_{4} \mathrm{O}_{12}(L n=\mathrm{La}, \mathrm{Pr}, \mathrm{Nd}, \mathrm{Sm}, \mathrm{Eu}, \mathrm{Gd}, \mathrm{Tb}$, Dy) collected at (a) $300 \mathrm{~K}$ and (b) $100 \mathrm{~K}$.

Figure 5. (a) Temperature dependence of the magnetic susceptibility for $L n \mathrm{Cu}_{3} \mathrm{Fe}_{4} \mathrm{O}_{12}$ on $\mathrm{ZFC}$ mode. Applied external field was $1 \mathrm{kOe}(\mathrm{Ln}=\mathrm{Sm}, \mathrm{Eu}, \mathrm{Gd}, \mathrm{Tb}, \mathrm{Dy}, \mathrm{Ho}, \mathrm{Er}, \mathrm{Tm}, \mathrm{Yb}, \mathrm{Lu})$ and $10 \mathrm{kOe}(\mathrm{Ln}=\mathrm{La}, \mathrm{Pr}, \mathrm{Nd})$. (b) Isothermal magnetization for $\mathrm{LnCu}_{3} \mathrm{Fe}_{4} \mathrm{O}_{12}(\mathrm{Ln}=\mathrm{La}-\mathrm{Lu})$ measured at $5 \mathrm{~K}$.

Figure 6. Temperature dependence of the electrical resistivity for $L n \mathrm{Cu}_{3} \mathrm{Fe}_{4} \mathrm{O}_{12}$ upon cooling. The resistivity was normalized to the values at $400 \mathrm{~K}(\mathrm{La}), 350 \mathrm{~K}(\mathrm{Pr}, \mathrm{Nd}$ ), and $300 \mathrm{~K}$ (others). The insets show the thermal hysteresis for $\mathrm{Ln}$ = (a) La, Nd, Gd and (b) Dy, Lu.

Figure 7. The $r_{L n}$ dependence of the (a) bond lengths and bond angle, (b) BVS (left axis), GII, and bond discrepancy (right axis). The data for $\mathrm{Ln}^{3+} \mathrm{Cu}_{3}^{2+} \mathrm{Fe}^{3.75+}{ }_{4} \mathrm{O}_{12}$ near the room temperature are adopted, using the $400 \mathrm{~K}$ data for $\mathrm{LaCu}_{3} \mathrm{Fe}_{4} \mathrm{O}_{12}, 350$ $\mathrm{K}$ for $\mathrm{PrCu}_{3} \mathrm{Fe}_{4} \mathrm{O}_{12}$, and $300 \mathrm{~K}$ for the others. The $r_{L n}$ values in the eight-coordination $(\mathrm{CN}=8)$ are adopted. ${ }^{31}$ The lines and curve are guides for the eyes.

Figure 8. (a) CT transition temperature versus GII for $L n \mathrm{Cu}_{3} \mathrm{Fe}_{4} \mathrm{O}_{12}(L n=\mathrm{La}, \mathrm{Pr}, \mathrm{Nd}, \mathrm{Sm}, \mathrm{Eu}, \mathrm{Gd}, \mathrm{Tb})$. The GII values are adopted at $400 \mathrm{~K}$ for $\mathrm{LaCu}_{3} \mathrm{Fe}_{4} \mathrm{O}_{12}, 350 \mathrm{~K}$ for $\mathrm{PrCu}_{3} \mathrm{Fe}_{4} \mathrm{O}_{12}$, and $300 \mathrm{~K}$ for the other $L n \mathrm{Cu}_{3} \mathrm{Fe}_{4} \mathrm{O}_{12}(L n=\mathrm{Nd}, \mathrm{Sm}, \mathrm{Eu}, \mathrm{Gd}$, $\mathrm{Tb}$ ). The line is a guide for the eyes. (b) Correlation between $d_{L n}$ and $d_{\mathrm{Fe}}$. The data are adopted for that at $400 \mathrm{~K}$ for $L n=$ 
$\mathrm{La}, 350 \mathrm{~K}$ for $\mathrm{Ln}=\mathrm{Pr}$, and $300 \mathrm{~K}$ for $\mathrm{Ln}=\mathrm{Nd}, \mathrm{Sm}, \mathrm{Eu}, \mathrm{Gd}, \mathrm{Tb}, \mathrm{Dy}, \mathrm{Ho}, \mathrm{Er}, \mathrm{Tm}, \mathrm{Yb}, \mathrm{Lu}$. Red (blue) markers represent the compounds transforming to $\mathrm{CT}(\mathrm{CD})$ phase at low temperature.

Figure 9. Electronic phase diagram for $\mathrm{LnCu}_{3} \mathrm{Fe}_{4} \mathrm{O}_{12}$. Red squares (blue circles) represent the CT (CD) transition temperatures, which were determined by XRD data for $\mathrm{Ln}=\mathrm{La}, \mathrm{Pr}, \mathrm{Nd}, \mathrm{Sm}, \mathrm{Eu}, \mathrm{Gd}, \mathrm{Tb}$, and ferromagnetic transitions for $L n=$ Dy, Ho, Er, Tm, Yb, Lu. The PM-M, FerriM-S, and AFM-I regions represent the paramagnetic-metal, ferrimagnetic-semiconductor, and antiferromagnetic-insulator phases, respectively. 
(a)

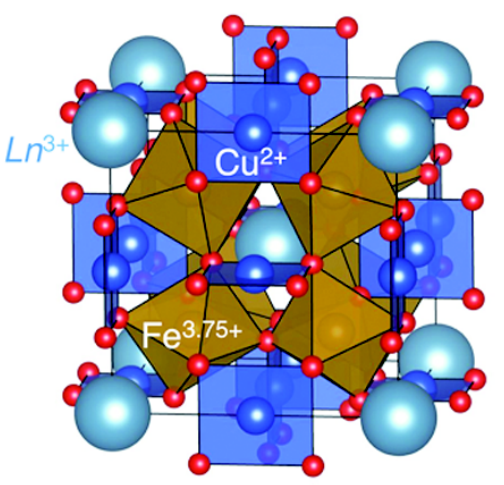

(b)

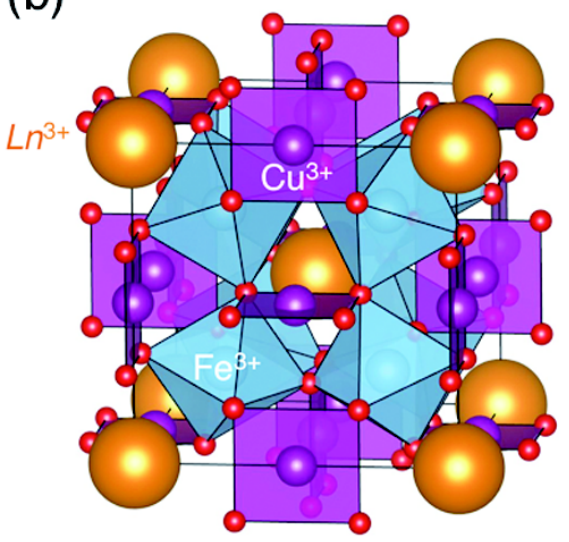

(c)

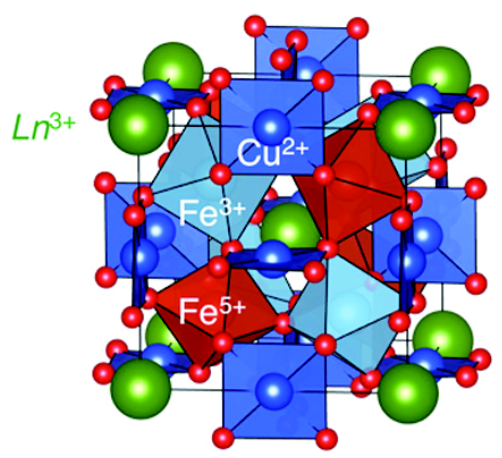

Figure 1 

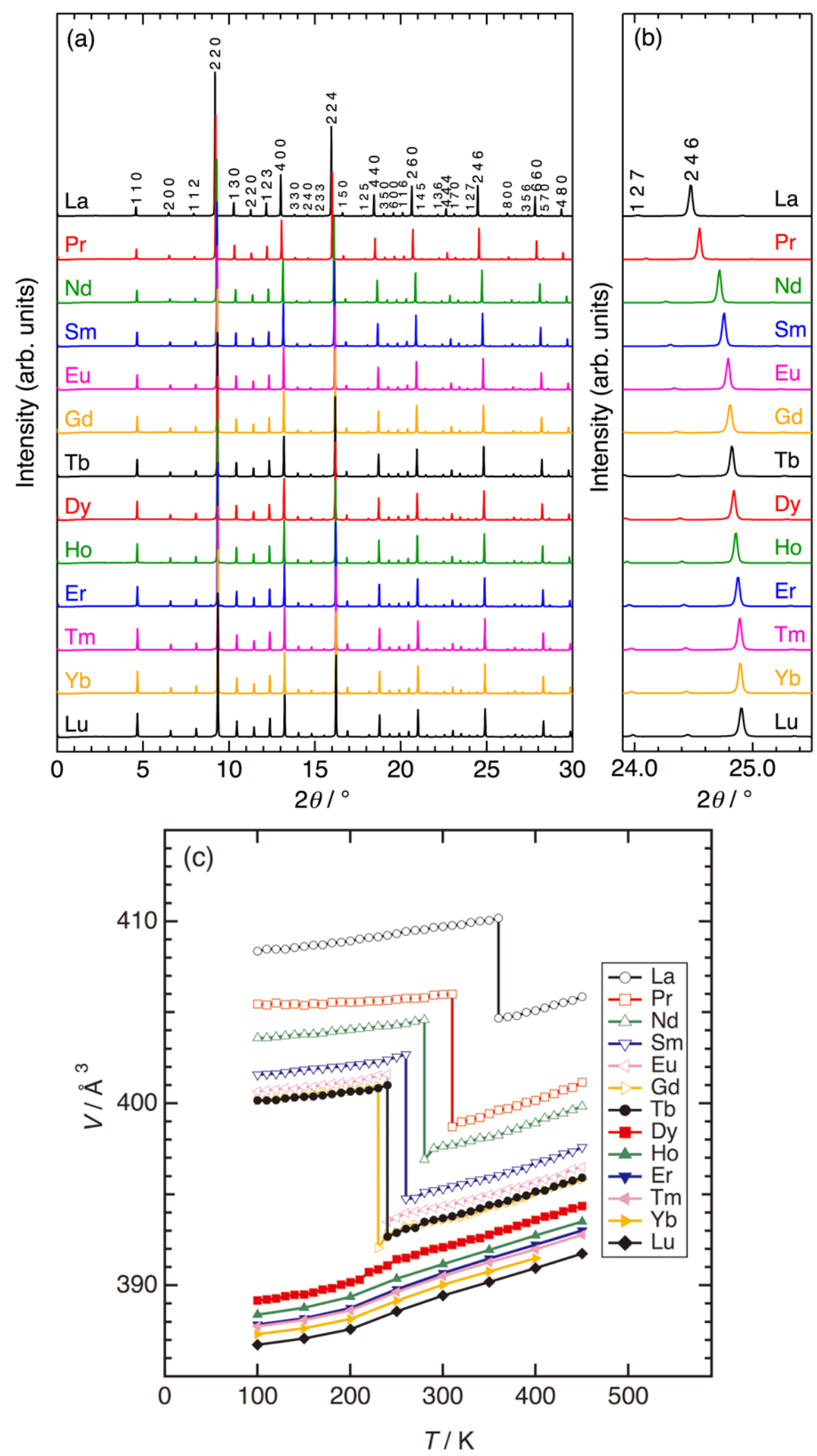

Figure 2 

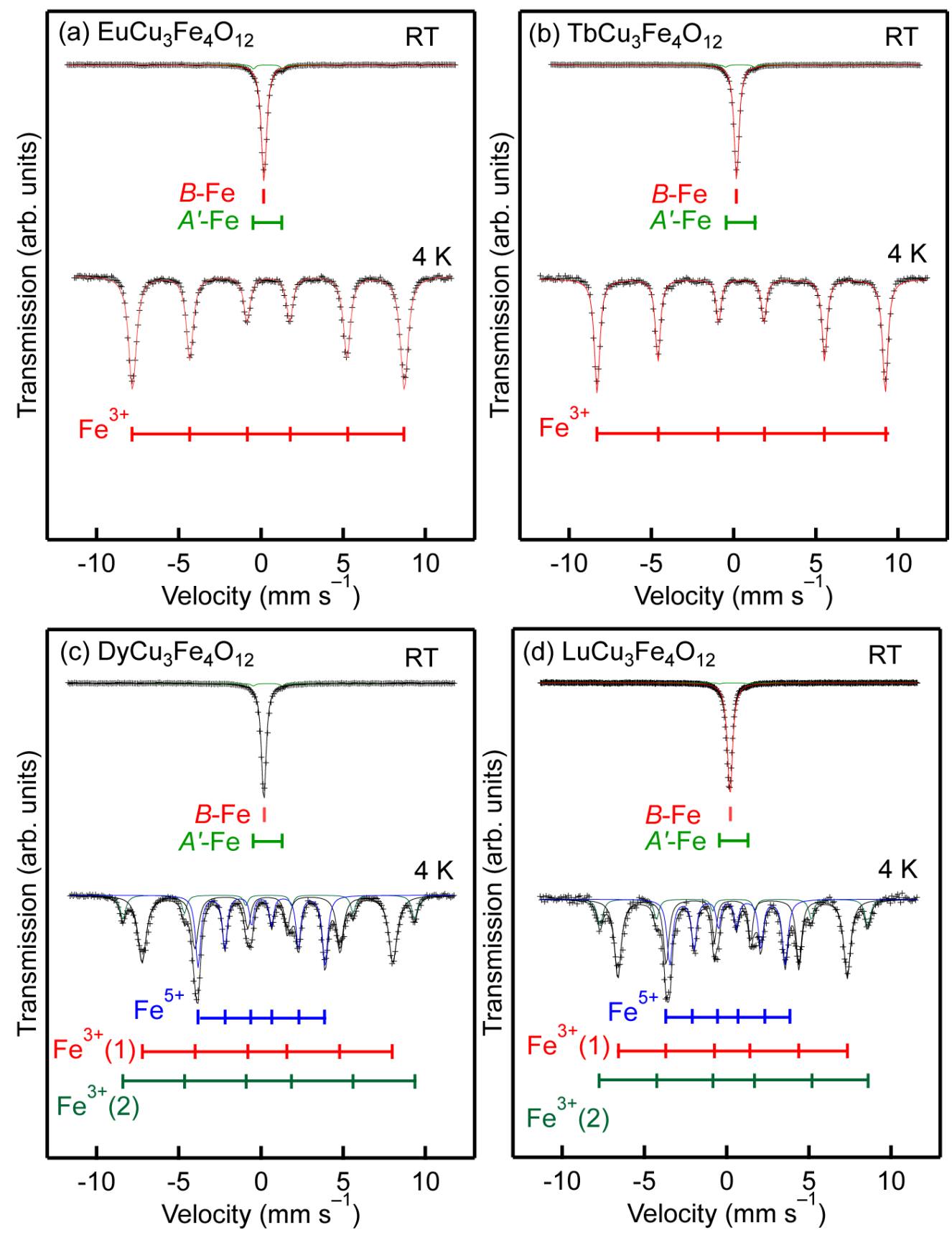

Figure 3 


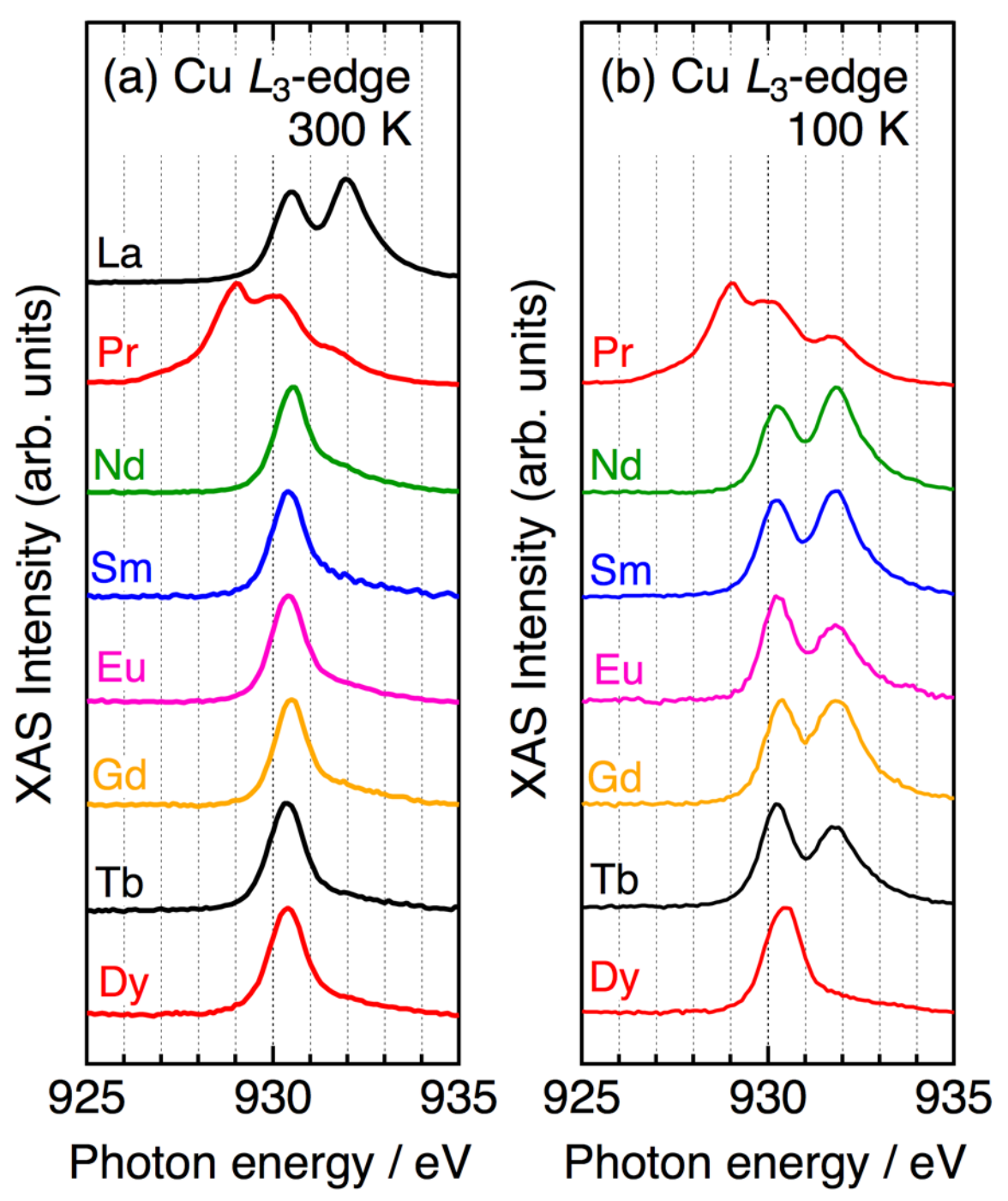

Figure 4 

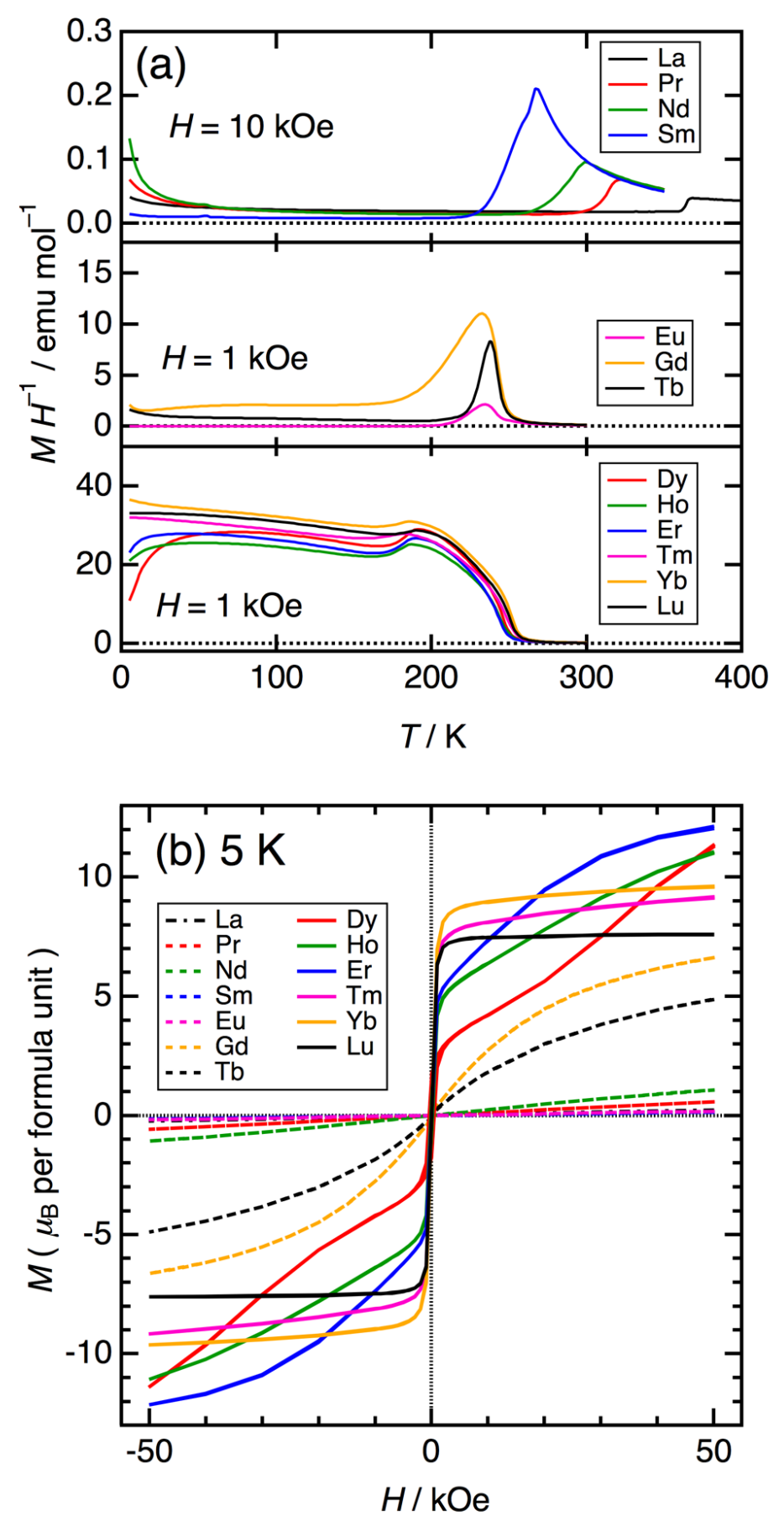

Figure 5 

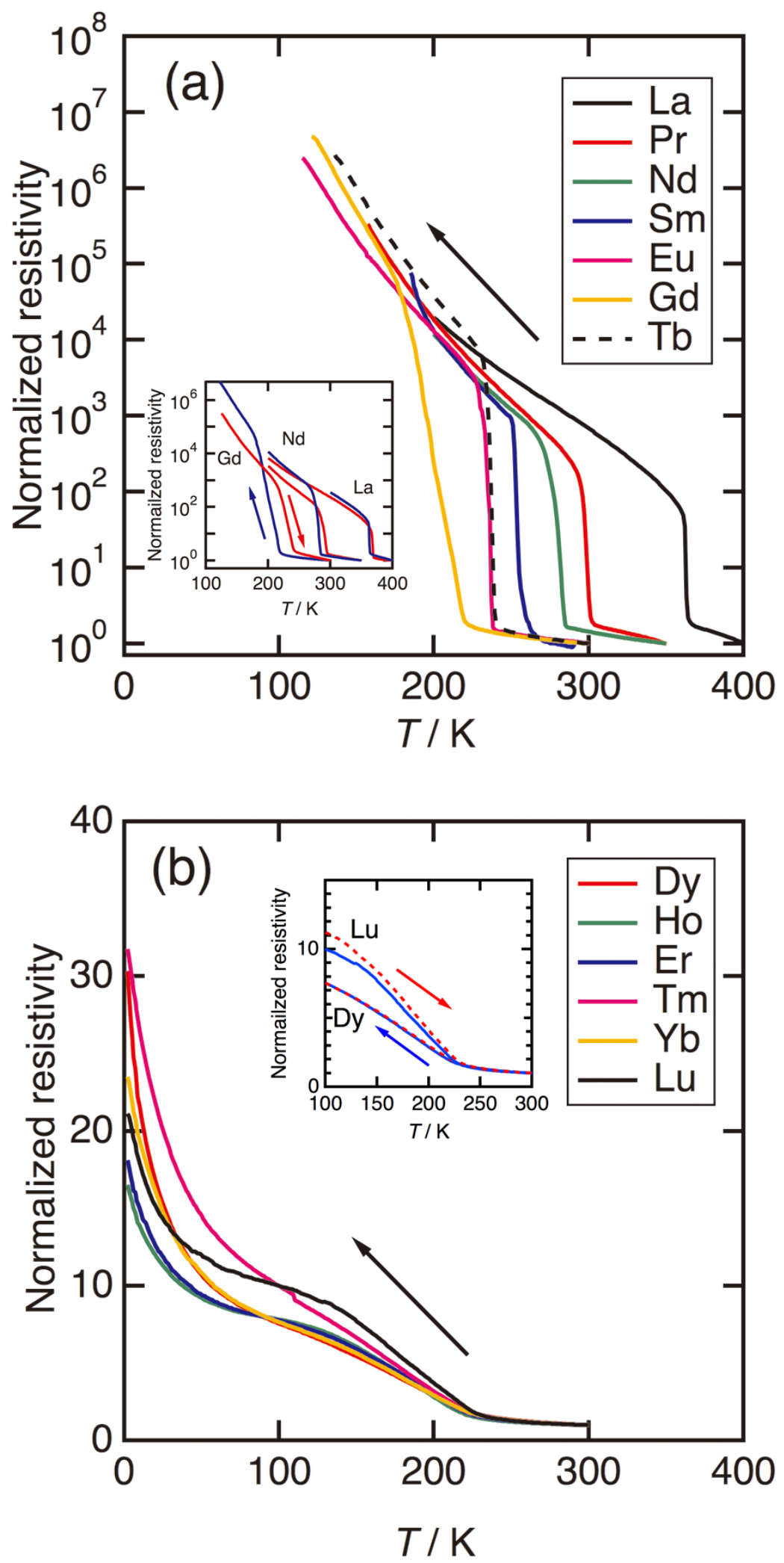

Figure 6 

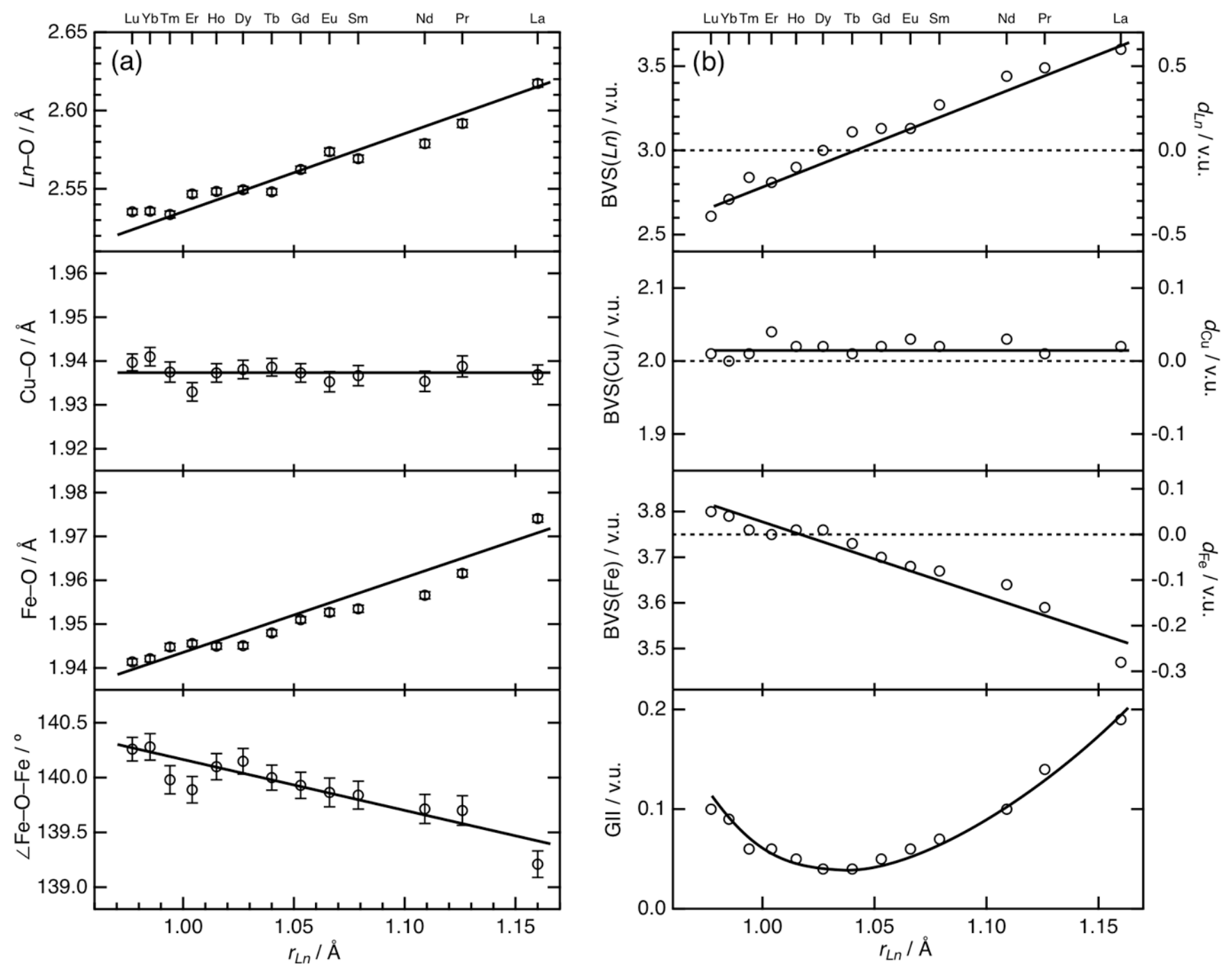

Figure 7 


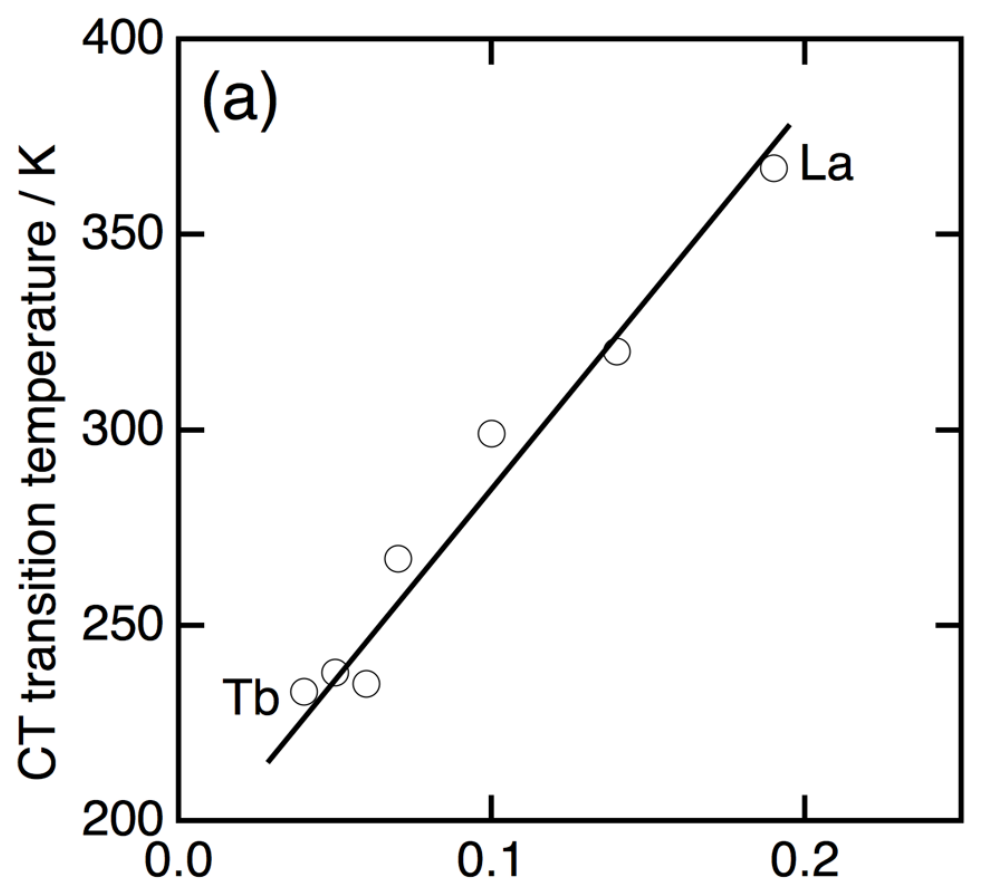

Gll / v.u.

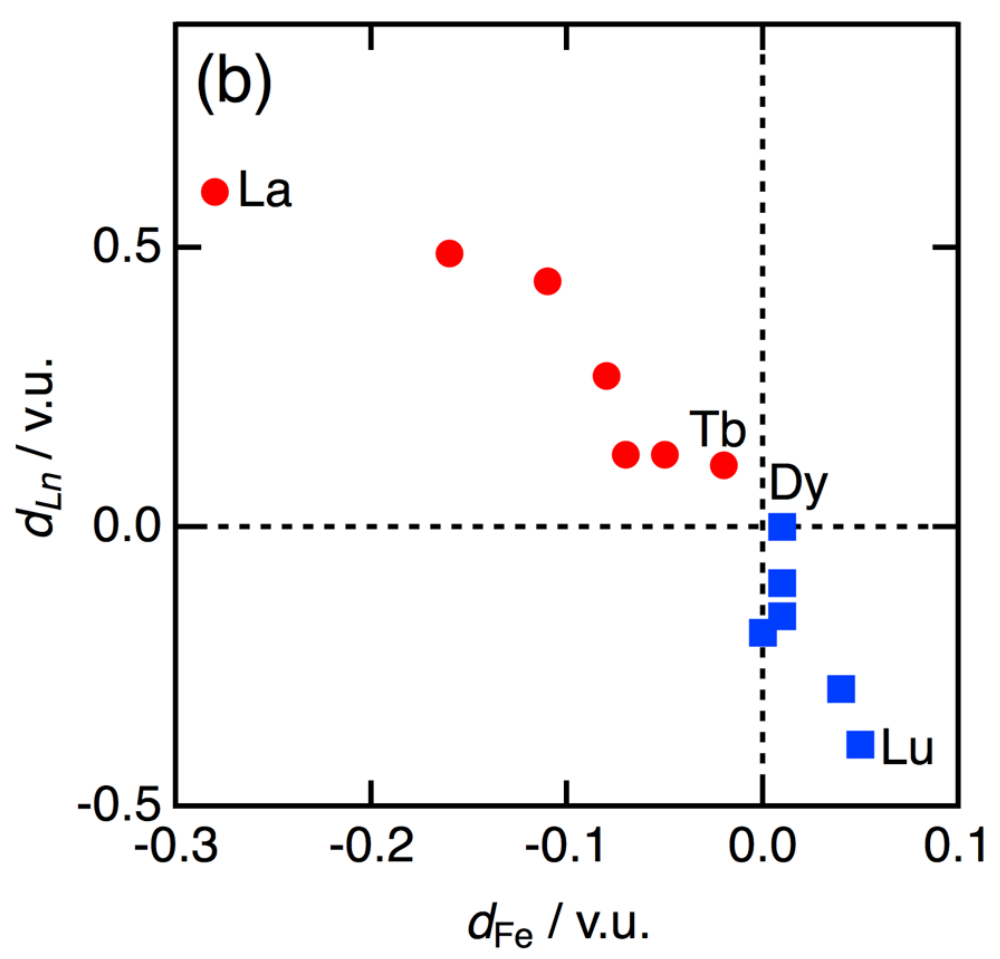

Figure 8 


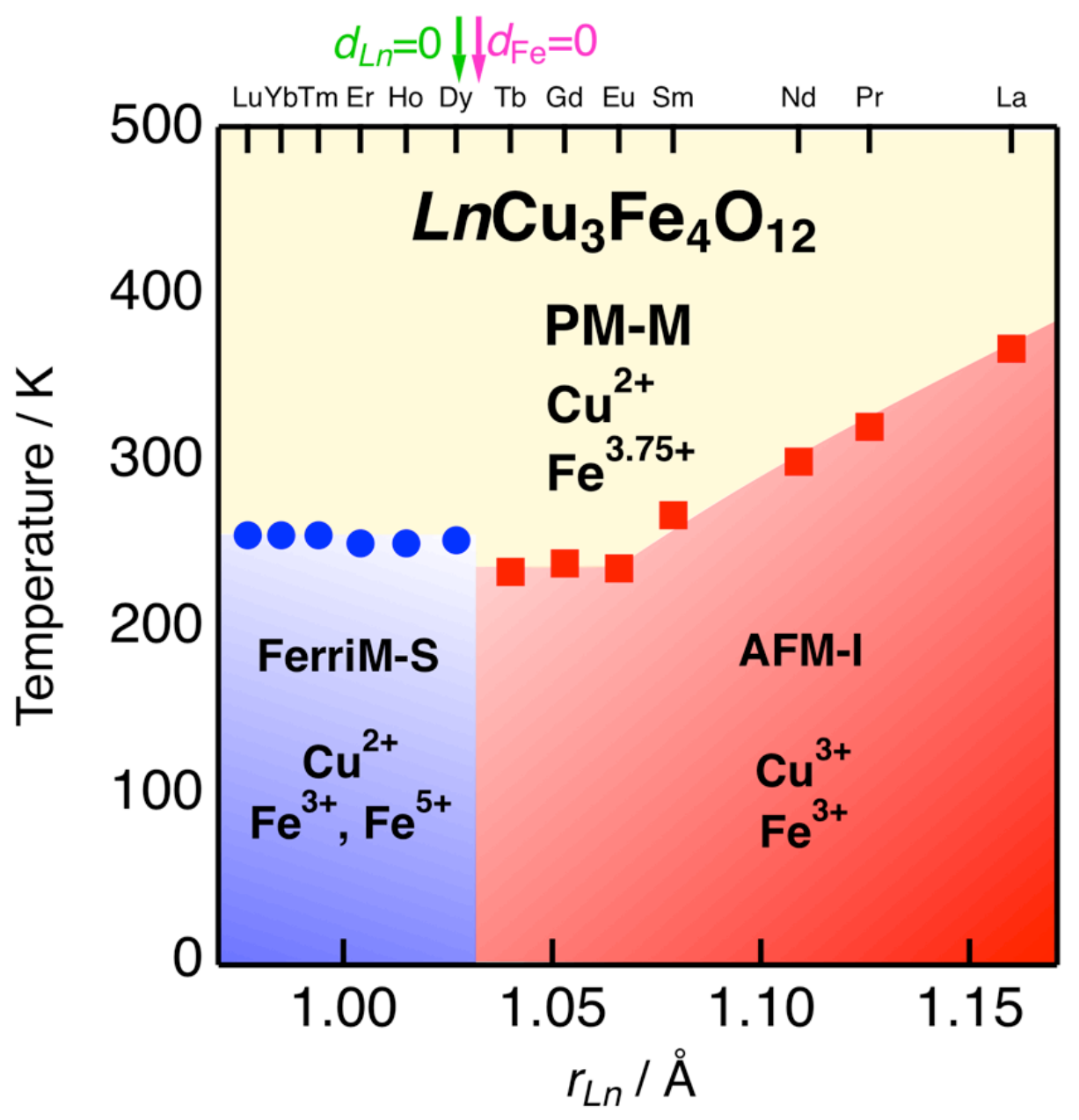

Figure 9 


\section{Table of Contents Synopsis}

Unusual electronic phase transitions in the $A$-site ordered perovskites $\operatorname{Ln}^{3+} \mathrm{Cu}^{2+}{ }_{3} \mathrm{Fe}^{3.75+}{ }_{4} \mathrm{O}_{12}$ ( $L n$ : lanthanide) are investigated.

$L n \mathrm{Cu}_{3} \mathrm{Fe}_{4} \mathrm{O}_{12}$ with larger $L n$ ions $(L n=\mathrm{La}, \mathrm{Pr}, \mathrm{Nd}, \mathrm{Sm}, \mathrm{Eu}, \mathrm{Gd}, \mathrm{Tb})$ show an intersite charge transfer transition $\left(3 \mathrm{Cu}^{2+}+\right.$

$\left.4 \mathrm{Fe}^{3.75+} \rightarrow 3 \mathrm{Cu}^{3+}+4 \mathrm{Fe}^{3+}\right)$. In contrast, $L n \mathrm{Cu}_{3} \mathrm{Fe}_{4} \mathrm{O}_{12}$ with smaller $L n$ ions $(L n=\mathrm{Dy}, \mathrm{Ho}, \mathrm{Er}, \mathrm{Tm} \mathrm{Yb}, \mathrm{Lu})$ transform into a charge-disproportionated $\left(8 \mathrm{Fe}^{3.75+} \rightarrow 5 \mathrm{Fe}^{3+}+3 \mathrm{Fe}^{5+}\right)$ and charge-ordered phase.

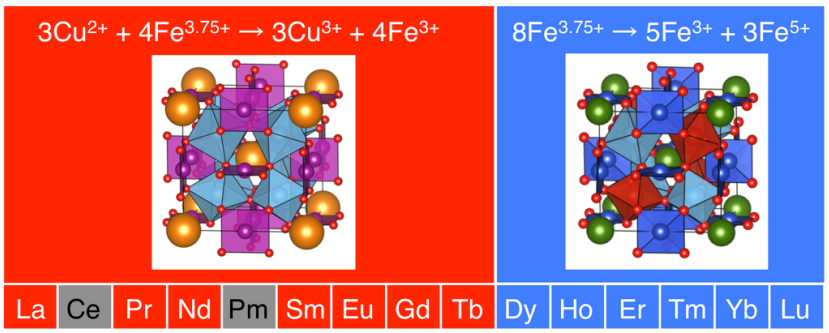

TOC image 